\title{
PATHS OF TECHNOLOGY UPGRADING IN THE BRICS ECONOMIES**
}

\author{
Iciar Dominguez Lacasa ${ }^{1}$, Björn Jindra ${ }^{1,2}$, Slavo Radosevic* ${ }^{3}$ \\ and Mahmood Shubbak ${ }^{1}$ \\ ${ }^{1}$ University of Bremen \\ Hochschulring 4, 28359 Bremen, Germany \\ ${ }^{2}$ Copenhagen Business School \\ Solbjerg Plads 3, 2000 Frederiksberg, Denmark \\ *corresponding author \\ ${ }^{3}$ University College London \\ Gower St, London WC1E 6BT, UK \\ s.radosevic@ucl.ac.uk
}

Paper published in 'Research Policy' September 2018

Pre-publication version

DOI: 10.1016/j.respol.2018.08.016

\begin{abstract}
This paper explores technology upgrading of BRICS economies based on a threepronged approach, which distinguishes between the intensity of technology upgrading, structural change and global interaction. We develop a statistical framework based on patent indicators to measure technological upgrading and apply it to BRICS economies in the period 1980 to 2011 . The paper shows that there is no single path of technology upgrading. Instead, we find several unique paths with different trade-offs between intensity, structural change and the nature of global interaction. All BRICS economies display increased generation of frontier technological activities, while China and Russia have also increased the intensity of behind frontier technological activities. China has also diversified its technology knowledge base and entered into dynamic frontier areas. With increasing intensity of frontier technology activities of the BRICS, the relative, but not absolute, importance of foreign actors and international collaboration has declined. However, BRICS economies seem to lack the organisational and complementary capabilities to match the extent of technology sourcing from abroad, observed in high income countries. Our result represents the application of a new conceptual framework and contributes to assess the sustainability of innovation based growth among BRICS.

\footnotetext{
** Research that form the basis for this paper has been partly funded from the European Union's Seventh Framework Programme (FP7/2007-2013) under grant agreement no 290657 “Growth-Innovation-Competitiveness: Fostering Cohesion in Central and Eastern Europe" (GRINCOH) is gratefully acknowledged
}

Keywords: technology upgrading, BRICS, patent indicators, comparative analysis. 


\section{INTRODUCTION}

The process of structural transformation of the global economy, in which the world's economic centre of gravity has been gradually moving towards the East and South, from OECD members to emerging economies, has been denoted by the OECD (2010) as 'shifting wealth'. This suggests that the rise of the emerging economies will inevitably have major global effects regarding distribution, and also affect the generation of global resources and knowledge. The start of the $21^{\text {st }}$ century witnessed the emergence of multi-polar growth with large developing economies as the newest and the most dynamic growth poles (Lin \& Rosenblatt, 2012). Among the emerging economies the so-called BRICS - Brazil, Russia, India, China and South Africa - has received particular attention. However, it is not certain and obvious that a blunt distinction between advanced and emerging economies is very helpful to understand the future growth trajectories of the emerging economies. Equally, putting all BRICS into one basket may blind us to understanding the differences in their growth trajectories. Whether the growth of emerging economies and BRICS in particular is sustainable depends on the extent of their technology upgrading, and this cannot be answered in general for all emerging economies or all BRICS. Whether the initial opening of emerging economies (shifting wealth I) will stretch into shifting wealth /I or sustainable technology-based growth requires a more nuanced exploration of individual countries (OECD, 2013).

In fact, it has been suggested that technological development is a binding constraint for sustained growth - in particular for middle-income countries (Lee \& Kim, 2009; Lee, 2013). The new Schumpeterian perspective argues that drivers of growth are different for countries at various income and technological levels (see, for example, Aghion \& Howitt, 1992). By the same token, we can infer that there are no universal metrics by which growth (including technologybased growth) can be measured. Growth theory shows that technology is an important growth 
factor in economic catch-up, but it cannot be reduced to a narrowly defined single variable such as R\&D or exogenously derived total factor productivity. Technology as a driver of growth is a multidimensional phenomenon. This is well reflected in policy-relevant frameworks like the Global Competitiveness Index or the Global Innovation Index which suggests that there is a need for conceptualisations of technology-based growth as a multi-dimensional phenomenon.

Against this background, there has been a call for new metrics to understand how technology upgrading takes place - emphasising the challenges of middle-income countries (Radosevic \& Yoruk, 2016). In response to this call, we extend recent models that differentiate (1) the intensity of technology upgrading reflected in different types of capabilities; (2) the breadth of technology upgrading; and (3) the relevance of global interaction for technological upgrading (see Radosevic \& Yoruk, 2016). We conceptualise technology upgrading as an outcome of the interaction of these three dimensions and derive a set of generic hypotheses on technology upgrading. We develop a multi-dimensional statistical framework based on patent indicators to measure technological upgrading for the BRICS economies in comparison to selected advanced economies (EU15, US and Japan) in the period of 1980 to 2011. The value of this investigation is in discovering technology profiles (paths) of different BRICS and in demonstrating the viability of the approach to other emerging economies. We advance the state-of-the-art by developing a measurement approach based on the concept of technology upgrading. This is a multidimensional conceptual framework which is open to sensitivities of different levels of development. It is empirically informed but also has theoretical relevance. We consider it as an appreciative theorising framework, which aims to overcome a common weakness of composite indicators that often represent 'measurement without theory' (Koopmans, 1947).

The paper shows that there is no single path of technology upgrading within the group of BRICS economies. Instead, we find evidence of several unique profiles of technology upgrading with 
different trade-offs between intensity, structural change and the nature of interaction with the global economy.

The next section develops the theoretical framework and derives general hypothesis about the characteristics of technology upgrading processes. Section 3 outlines the methodology to tests the hypothesis on the BRICS economies using patent indicators. The empirical analysis is presented in section 4. Finally, section 5 discusses the results.

\section{CONCEPTUAL FRAMEWORK FOR TECHNOLOGY UPGRADING}

Conventional models of technological development or upgrading are based on either exogenous model of growth (Solow, 1957) or endogenous growth theory (Romer, 1990). The Solow model cannot explain technology and treats it as unexplained part of growth, which makes it of very limited relevance for our research. In endogenous growth theory, R\&D is the primary source of innovation and growth. This might be less applicable to developing countries, and therefore it has been questioned whether endogenous growth theory pays sufficient attention to economic catch-up (Lin \& Rosenblatt, 2012).

A new Schumpeterian approach to growth has been developed by Aghion and Howitt (1992) who base their modelling on different distances of countries from the technology frontier. This enables them to distinguish between growth based on innovation and imitation which seems much closer to the real-world processes of growth and the catching up of developing economies.

Closely related to Schumpeterian modelling are different neo-Schumpeterian contributions which emphasise innovation capabilities as enabling factors for catch-up in developing and emerging economies (see, for example, Verspagen, 1991; Nelson, 1995; Nelson \& Pack, 1999; Lee, 2005; Fagerberg \& Godinho, 2005; Mazzeloni \& Nelson, 2007). 
Our framework follows from neo-Schumpeterian approach, but we also address the multidimensional nature of the technology which is an important, but poorly dealt with, dimension of economic growth. Our departing proposition is that technology upgrading is a multidimensional process. By this we mean that it is based on a broader understanding of innovation, which goes well beyond R\&D. It is also a multi-level process i.e. it is micro, mezzo and macro grounded. At its core is structural change in various dimensions: technological, industrial and organisational. Finally, it is also strongly shaped by global forces embodied in international trade and investment flows, interacting with local strategies pursued by host country firms and governments (Ernst, 2008; Lall, 1992; Radosevic \& Yoruk, 2014, 2016). We approach technology upgrading as a three-dimensional process. Thus, we differentiate between the intensity of technology upgrading as depicted by different types and levels of innovation, the breadth of technology upgrading in terms of changes to the structure of technological knowledge, as well as the role of global interaction in terms of inflows of foreign technology and coupling with domestic technological efforts.

\subsection{The intensity of technology upgrading}

The intensity of technology upgrading is about the accumulation of different types of capabilities, which also reflect the various technological levels of economies. Bell and Pavitt (1993; 1995) emphasised two kinds of accumulation processes within late industrialising firms and economies. One is the accumulation of technology embodied in physical capital and the associated human capital required to operate the facilities at given levels of efficiency. This has been described as production capability. This capability requires good operational efficiency as 
well as a skilled technical and blue-collar workforce. The other process, not well recognised in conventional growth analysis, is the accumulation of innovation capabilities ${ }^{1}$.

Bell (2009) argues that the first accumulation process is concerned with firms' capabilities to use existing technologies in production. This catching up can be reflected, for instance, in measures of productivity and the narrowing of productivity gaps over time between latecomer firms and firms at the world technology frontier. The second accumulation process is concerned with firms' capabilities to create new technology and change the technology they already use. This catching up is about closing the gap between copying or adopting existing technology on the one hand, and improving or creating it on the other (see also Kim, 1997). In this process, latecomer firms close the gap towards those of frontier-innovating firms. Catching-up along this dimension is harder to measure, but it can be assessed regarding the increasingly different levels of innovative capability (Lall, 1992) and the rate at which firms move through them (Ariffin \& Figueiredo, 2004).

The empirical firm-level literature on capabilities documented several successful cases of upgrading from production capability to innovation capability by latecomer firms in East Asia (Hobday, 1995; Hobday et al., 2004; Ernst, 2013), Latin America (Dutrenit, 2000) and Central and Eastern Europe (Radosevic \& Yoruk, 2004). However, production capabilities remain important as economies technologically upgrade. It is important to note that production capabilities and innovation capabilities as well as R\&D/knowledge intensity are present in each economy, to different degrees. Similar to R\&D, which is not only important in its role of knowledge generation but also in its role of knowledge absorption (Cohen \& Levinthal, 1989, 1990), production and innovation capabilities are reinforcing each other. This does not mean

\footnotetext{
${ }^{1}$ Bell and Pavitt $(1993 ; 1995)$ originally used the term 'technological capability' to describe what Bell (2009) refers to as 'innovation capability'. He argues that the notion of technological capability is commonly used, especially in literature about the advanced economies, to refer much more broadly to both production capacity and innovation capability - hence clouding the distinction that the authors originally wanted to highlight.
} 
that there is some fixed optimal proportion between different types of capabilities and/or R\&D. Equally, technology upgrading is not well represented by the increasing share of some of these activities and reduction of others. The individual importance of production capabilities, R\&D capabilities and innovation capabilities as drivers of growth varies according to their dependence on achieved income, technology levels and the structural features of the economy (Radosevic \& Yoruk, 2016). What matters are their interaction and complementarity and not only individual levels. A high share of world frontier technology activities in an economy with weak production capabilities (or where the rest of firms have weak absorptive R\&D capabilities) will lead to enclave type of growth with limited diffusion and productivity spillovers. In a stylised manner, we would propose the following hypothesis:

(H1) Countries at different income levels pursue varying degrees of production, innovation and R\&D activities. In that context, their technology upgrading is the best represented as complementary relationships between production, innovation and R\&D activities which cumulatively lead to increased technology intensity.

From this follows that technology upgrading is not a linear and autonomous process of growth of mutually independent production, technology and R\&D capabilities, but is a non-linear process involving several threshold levels (Radosevic \& Yoruk, 2016). The move from one stage to another stage is not guaranteed and requires a new set of mutually complementary technical, financial, and organisational preconditions. Our evidence is based on patent data and does not allow us to test for all three dimensions of increased technology intensity (production, innovation and R\&D activities). However, by using transnational and priority patents we are able to show the transition in technology upgrading from behind the technology frontier to technology frontier activities. 


\subsection{Breadth of technology upgrading}

Technology upgrading is more than the intensity or scale of technological activities we observe during catch-up. Past contributions point towards the importance of the extent or scope of structural factors. Early approaches have already depicted development as an evolving process that goes through several stages (see, for example, Rostow, 1960). This was based on the idea of industry life cycles and 'leading sectors', driving economic growth in specific stages. A common feature of these models is the assumption that 'all nations [go] through the same stages in the same order, though not necessarily at the same time' (von Tunzelmann, 1995, p. 69). However, there is not a general theory of structural change but a variety of theoretical approaches of different methodological nature that aim to explain structural shifts between broad sectors and among industries within these sectors (Krueger, 2008). There is a common understanding that technological changes affect structural change in the way that industries with relatively lower rates of productivity growth tend to shrink, in terms of shares, while those with higher rates of productivity growth expand. However, the empirical evidence on the role of structural change shows that it generates positive as well as negative contributions to aggregate productivity growth. Since many of these effects average out, structural change appears to have only a weak impact (Peneder, 2003).

So, instead of being focused on structural changes at the level of industries, it seems more appropriate to track variations in the structure of technological knowledge. Empirical results do not support the idea that growth is correlated with the share of the high-tech sectors (Sandven et al. 2005). We also find evidence for the adoption of high-tech activities in low-tech industries as well as low-tech activities in industries classified as high-tech i.e. intensive regarding R\&D (von Tunzelmann \& Acha, 2005). Instead of structural change being reflected in shares at the industry level, we observe a change in the nature of industries and services and their 
convergence. These changes are exemplified by the increasing role of knowledge-intensive business services (KIBS) as well as the growing importance of knowledge-intensive activities $(\mathrm{KIA})^{2}$ across all economic sectors (EC, 2011). Against this background, we would argue that the accumulation of production and innovation capabilities in catch-up is associated with changes in the underlying knowledge intensity. These changes reflect a structural change in knowledge generation and absorption towards a high share of high-technology knowledge and higher knowledge intensity of economic activities. We propose the following:

(H2) Low-income countries are more likely to be associated with a low share of knowledge-intensive activities, while middle-income and high-income increase their shares of knowledge-intensive economic activities.

The sectoral concentration of countries seems to follow a U-shaped pattern in relation to per capita income. Imbs and Wacziarg (2003) show that economies grow through two stages of diversification. At first, sectoral diversification increases, but there exists a level of per capita income beyond which the sectoral distribution of economic activity starts concentrating again. The knowledge base of the successful catching-up economies seems also to follow a non-linear, though inverse, trend. Lee (2013) shows that technological diversification, rather than specialisation, is one of the major factors in catching up to high-income levels. While New Structural Economics accounts (Lin 2012a,b; Lin \& Rosenblatt 2012) show the path to technology upgrading as based on 'copying industries' using latent comparative advantages in the transition from low to middle-income levels, Lee (2013) shows middle-income economies are taking 'detours' or temporary specialise in so-called short cycle technologies. He shows that

\footnotetext{
${ }^{2}$ KIBS are defined according to the NACE Rev. 1.1 as including the categories computer and related activities (NACE 72), research and development (NACE 73), and other business activities (NACE 74). KIA are defined as economic sectors in which more than $33 \%$ of the employed labour force have completed an academic tertiary education (ISCED 5 and 6 levels).
} 
Korea and Taiwan have entered into smaller number of knowledge areas with great technological opportunities but in an increasing number of sectors. However, as Korea and Taiwan continued to grow they have successfully moved to the high-income group by a process of substantial technological diversification. Against this background, we would expect that:

(H3) Low-income countries predominantly imitate foreign technologies and are characterised by a narrow specialisation of the domestic technological knowledge. Successful middle-income countries may temporary specialise in narrow areas with high technological opportunities, but the path of technology upgrading (though possibly nonlinear) is characterised by increasing knowledge diversification.

\subsection{Global interaction in technology upgrading}

Growth and technology upgrading are never entirely autonomous processes but linked to global interaction. For example, Akamatsu (1962) describes technology upgrading as an interactive process between 'leaders' and 'followers'. This argument can be tied to different lines of development-oriented research, which relate to foreign direct investment (FDI), learning by importing/exporting, as well as upgrading in global value chains (GVCs). Arguably, all three channels of global interaction potentially affect the intensity of technological upgrading in the catch-up process.

Inward FDI has been traditionally associated with a centrally accumulated technological advantage originating in the home country, which is transferred to the host country where it diffuses to the domestic economy. In fact, Findlay (1978) argued that the potential for technological diffusion via FDI is positively related to the relative technology gap between the home and host economy. He referred to the 'contagion effect' whereby technical innovations are most effectively copied when there is personal contact between those who already have 
knowledge of the innovation and those who eventually adopt it (Nelson, 1968; Mansfield 1961, 1968).

Wang and Blomström (1992) criticised this approach in which a host country's production efficiency is simply modelled as an increasing function of foreign capital. They explicitly recognise the costs associated with technology transfer in multinational enterprises (MNEs), as suggested by Teece $(1976,1977)$, and learning costs of domestic firms. Thus, FDI externalities depend positively on the technical and managerial competence of the foreign subsidiary as well as the domestic firm's decision to invest in learning (Marin \& Bell, 2006; Castellani \& Zanfei, 2006; Damijan et al., 2013; Jindra, 2011; Giroud et al., 2012).

Emerging market firms can also improve their innovation capabilities through outward FDI (Mathews, 2006; Li, 2010; Ramamurti, 2012; Narula, 2012). Some investigations demonstrated the existence of knowledge-driven outward FDI strategies (see, among others, Makino et al., 2002; Buckley et al., 2007; Jindra et al., 2016).

There is also an established line of research, which points towards technological learning from importing/exporting (Grossman \& Helpman, 1991; Drivas et al., 2016; Eaton \& Kortum, 2001; Keller, 2002; Keller \& Yeaple, 2009). Given that foreign affiliates often show higher levels of imports and/or exports compared to domestic firms, technology accumulation via trade and FDI can be considered as complementary effects. International licensing or knowledge flows in a disembodied form also represents important channels of technology transfer. However, these are closely tied and thus inseparable from either trade or FDI flows.

In the GVC literature upgrading manifests itself through various forms: efficiency gains by reorganising the production system or introducing superior technology; product upgrading, where a firm moves into more sophisticated product lines; functional upgrading, where a firm acquires new functions (or abandons existing ones) to increase the overall skill content of 
activities (Kaplinsky \& Morris, 2001; Humphrey \& Schmitz, 2002, 2004; Sturgeon \& Gereffi, 2009; Gereffi \& Fernandez-Stark, 2011). Therefore, the entry of emerging market firms into GVCs creates opportunities for technological upgrading through learning and interaction. This leads to the following hypothesis:

(H4) In low-income countries, global interaction is of high relevance to gain access to frontier technology. However, low-income economies have weak organisational capabilities and their patentable knowledge is often commercialized by foreign applicants. As countries' incomes grow and technological capabilities upgrade, they can enter into a process of knowledge co-generation. In high-income economies, the generation of frontier technology is based much more on domestic actors who can actively source and commercialise technological knowledge from abroad.

In a stylised manner, we argue that low-income countries primarily benefit from technology transfer via inward FDI and learning by exporting/importing. At this stage, low-income countries have weak organisational capabilities to commercialise their own patentable knowledge. At later stages, middle-income countries start to engage in upgrading processes, primarily process and product upgrading and are gradually able to enter into knowledge cogeneration activities with foreign partners. Advanced middle-income countries also begin to engage in functional upgrading to knowledge-intensive business functions, as well as to interchain upgrading and the establishment of domestic lead firms. We also begin to observe increasing levels of outward FDI, which is partially motivated by technology-seeking motives and reverse technology transfer to compensate for home country disadvantages.

\subsection{Technology upgrading as an outcome of interaction between its three dimensions}


The three dimensions of technology upgrading, as outlined above, are not isolated but complementary and mutually dependent. For example, a key point that emerges from the literature is that technology upgrading can be linked to inflows of foreign knowledge and technology. However, this needs to be coupled with intensive domestic technology efforts (Radosevic, 1999; Pietrobelli \& Rabellotti, 2011). Otherwise, upgrading effects due to global interaction remain limited or do not develop at all. Arguably, the key to catch-up is leverage of domestic innovation efforts with global industrial or knowledge networks (Ernst, 2008). Criscuolo and Narula (2008) argue that assimilation of foreign knowledge is not only confined to catching-up economies but is also carried out by countries at the frontier-sharing phase. Hence, the magnitude of knowledge inflows and their coupling to domestic innovations efforts are critical dimensions of technology upgrading.

Furthermore, the structural change in economy and industry has direct effects on the intensity of technology upgrading. For example, R\&D intensities of economies are strongly determined by the economic structure to the extent that accounting for industrial structure substantially affects the traditional country rankings of R\&D intensity (Mathieu \& Pottelsberghe, 2010). Rodrik (2016) documents a significant premature deindustrialization trend in groups of developing economies in recent decades that goes considerably beyond the advanced, postindustrial economies. The premature deindustrialization reduces the knowledge intensity of these economies as manufacturing is still the main locus of R\&D activities.

Finally, the extent to which FDI, GVCs and trade can impact economic structure is the subject of a vast amount of literature, which looks at this interaction from their specific angles. In the case of FDI, this is about the extent to which FDI has direct versus indirect effects on other linked sectors, which can lead to structural change in the economy. In the case of GVC, the issue is tackled through different types of upgrading at micro-level which lead to different value 
added positions in international trade i.e. to different technology structure. Against this background, we would expect that:

(H5) Interactions among three components lead to nationally specific paths and profiles of technology upgrading. The scope for substitution between different dimensions does exist, but we would expect that cases of catching-up are characterised by dynamic complementarities between three components of technology upgrading.

The benefits of the multidimensional framework are not in a simple summation of outcomes on particular dimensions, but in the emerging profiles of technology upgrading. Catching-up economies are characterised by dynamic complementarities among three components, while lagging economies have numerous missing linkages among three components. Alternatively, they are lagging behind regarding the technology intensity of upgrading, despite positive structural changes or high openness towards the global economy. The emerging profiles that stem from interaction of three components may hopefully be much more informative regarding the sustainability of growth and the nature of technology upgrading in BRICS.

\section{METHOD}

The body of research on measuring countries' performance in growth, competitiveness and innovation offers a variety of composite indicators ${ }^{3}$. It is important to bear in mind that different indices treat 'technology' in different ways. Some of them cannot be taken as a direct measure of innovative performance. For example, the Global Competitiveness Index depicts the

\footnotetext{
${ }^{3}$ Examples are: the Global Competitiveness Index (WEF, 2012), the Knowledge Economy Index (Chen \& Dahlman, 2004), the World Competitiveness Report Index (by IMD), Technological capability of countries, (Archibugi \& Coco, 2004, 2005; Archibugi et al., 2009), UNIDO Industrial Performance Scoreboard, the Summary Innovation Index and the Global Innovation Index (both from the European Commission); the Technological Activity Index (by UNIDO); the Technological Advance Index (by UNCTAD), the Technology Achievement Index (reported in the Human Development Report 2001), and the S\&T Capacity Index (by RAND Corporation), the High-Tech Indicators (reported by the National Science Foundation's Science \& Engineering Indicators).
} 
quality of the current endowment of a country (including institutions) and among them also the technological activities as one of the determinants of growth. We confine ourselves to measuring technology upgrading, and we do not aim to unravel a complex picture of the institutional factors that determine growth and competitiveness of economies. Also, we do not aim at establishing a ranking, but the identification of different paths of technology upgrading to facilitate comparative research.

It is important to note that by capturing patterns of technology upgrading we focus on middleincome countries and catching-up processes in terms of innovation capabilities (Bell 2009). We do not aim at measuring production capability. For this purpose, we study patterns of technology upgrading by relying entirely on patent data. Analytically, we treat technology as a stock of knowledge separate from production, although in reality they are strictly interconnected (Bell \& Pavitt, 1997). Using exclusively patent-based indicators means that, similar to Archibugi and Coco (2005), we exclude production capability from innovation capability. The exclusive reliance on patents has costs in terms of capturing only a part of innovation efforts. Their intangible character is more appropriate as countries move up towards the technology frontier and less relevant for countries behind the technology frontier where intellectual property rights (IPRs) are not the dominant form of protection of technological know-how. This is especially important as innovation in latecomer economies is largely about adoption and improvements on imported machinery.

Catch-up in innovation capability can be measured by different levels of increasingly innovative capability (Lall, 1992; Bell, 2009). Using both transnational and priority patents, our approach tracks 'frontier' and 'behind frontier' technological activities. In other words, it captures different levels of innovation capability ranging from incremental technological improvements relevant for domestic markets (behind the technology frontier) up to more sharp and radical 
solutions relevant for international markets (at the technology frontier). A priority patent is the first patent application filed to protect an invention. Priority filings include the overall technology effort: incremental innovation relevant for domestic economies (usually patented first and exclusively in national patent offices) as well efforts at the technology frontier (usually protected directly as transnational patent applications). Transnational patent applications include all Patent Cooperation Treaty (PCT) applications (whether transferred to the European Patent Office EPO or not) and all direct EPO applications without a precursor PCT application ${ }^{4}$ (Frietsch \& Jung, 2009). Indicators based on transnational patent applications reflect the innovation capability relevant for competitiveness in international markets. Therefore, we use transnational patent applications as indicator for frontier technological activities in our analysis. According to de Rassenfosse et al. (2013) indicators based on priority patents are more effective in capturing inventive technological activities in catching-up economies which are closer to incremental innovation, with lower commercial potential and which often take place behind the technology frontier. For advanced economies, the difference between transnational patent applications and priority filings is very low as their firms operate closer to or at the technology frontier when compared to catching-up economies. A priority filings count represents the total number of patent families, regardless of their spatial protection scope (i.e. overall technological intensity). The transnational patent applications indicator represents the number of families that are protected in global (across border) markets. Therefore, we use in our analysis a novel indicator of 'behind frontier' technological activities, which is defined as the number of patent families that do not contain transnational applications. This indicator is calculated as the mathematical difference between the priority filings count and the

\footnotetext{
${ }^{4}$ The origin of the invention is defined by the country of residence of the inventor. If an application involves inventors from different countries, the national assignment will be fractional depending on the number of countries involved.
} 
transnational patent applications count. This way we can better differentiate between frontier and behind-the-frontier technological activities.

Using patents has some important advantages for the empirical analysis of technology upgrading. We can derive long and consistent time series as well as define technological fields using the patent classification. Unlike macroeconomic indicators, innovation capabilities change very slowly even during periods of deep economic crises or high growth (Archibugi et al., 2009). By using patents, we can easily detect stock and flows and thus depict, much better compared to other indicators, changes in technology intensity as well as a structural change in technological knowledge. In sum, the benefits of using patent-based indicators surpass the costs as they enable us to track the changing nature of technological knowledge as countries move from 'followers' to 'leaders' and as they shift from behind frontier technology effort to world frontier technology efforts.

\section{ANALYSIS}

In this section, we implement the comparative analysis of technology upgrading processes in the BRICS economies between 1980 and 2011. The analysis is structured along the three conceptual dimensions of technology upgrading. Each dimension is proxied by the specific set of patent indicators. ${ }^{5}$ Finally, we provide an integrated analysis by discussing changes in the relative position of the BRICS economies along the three dimensions comparing changes in selected indicators over time.

\subsection{INTENSITY OF TECHNOLOGY UPGRADING}

The intensity of technology upgrading in the middle-income countries considered is reflected in the accumulation of innovation capability. We differentiate between (i) innovation capability

\footnotetext{
${ }^{55}$ Table A1 in the annex includes the descriptions and data sources of the indicators presented in this section
} 
pushing the world technology frontier and (ii) domestic innovation capability behind the world technology frontier.

\subsubsection{Innovation capability pushing the world technology frontier}

To measure domestic technological activities pushing the technology frontier we rely on transnational patent applications of domestic inventions (TN). Figure 1 gives the number of transnational patent applications per 1 billion GDP (in US\$ constant prices 2005) for the period 1980 to 2011 (see in Annex Tables A1 and A2). The indicator adjusts the scale of technological upgrading for the size of the economy and thus measure relative 'technology (patent) intensity' of the economy. We present the patent-based indicators for Brazil, Russia, India, China, and South Africa and add the respective indicators for the US, EU15 and Japan as a reference for high-income economies.

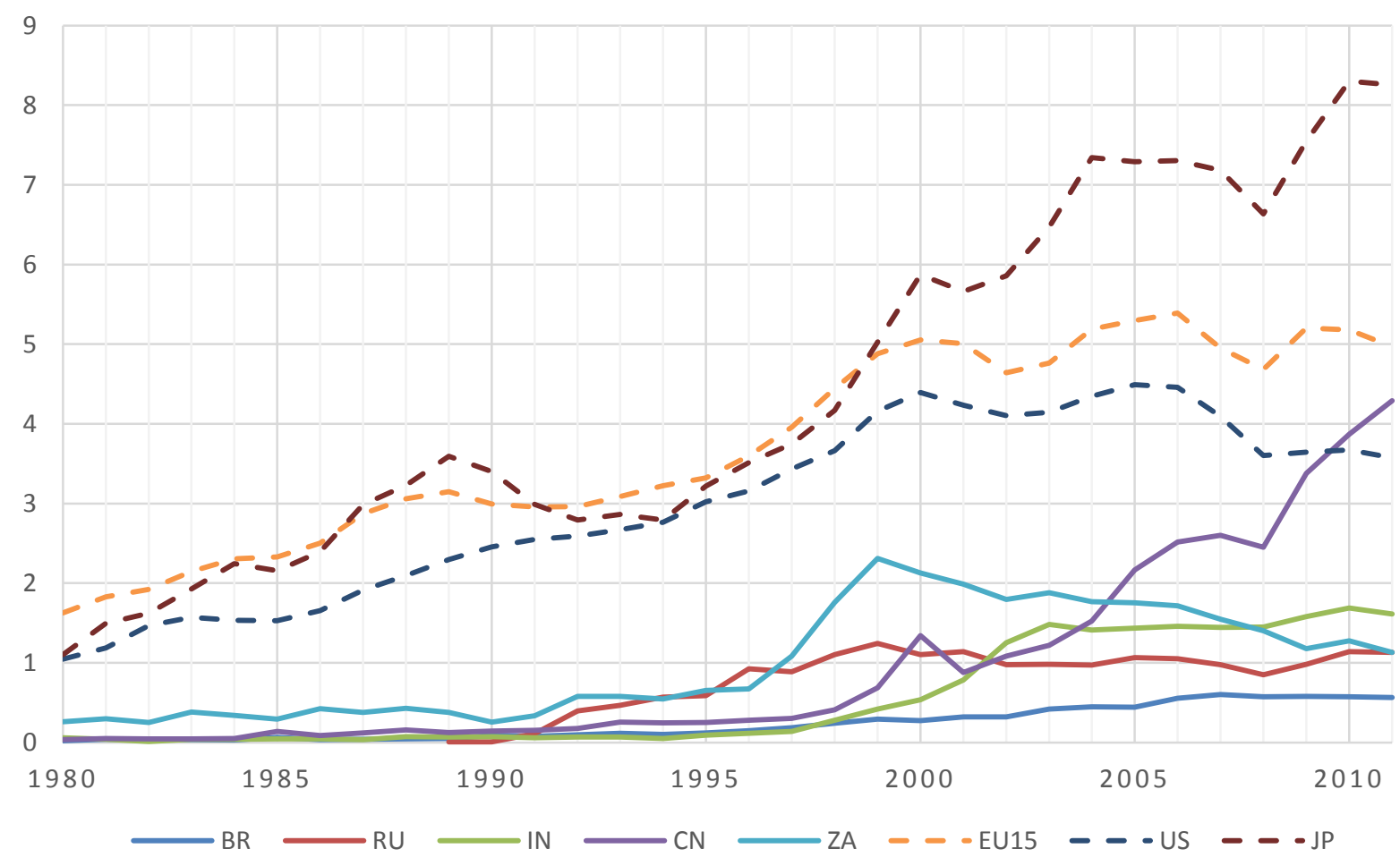

Source: Indicators elaborated by the authors using data from OECD REGPAT and World Bank.

Figure 1: Frontier patent applications per 1 billion of GDP (in US \$) per priority year 
The most striking trend is that the Chinese economy moved up into the group of high-income economies. In 2009/2010 China's scale of frontier activities per unit of output surpassed the level of the US. This catch-up does not apply to any other BRICS economy, although these economies witnessed a twofold increase in their frontier activities since the mid-1990s.

\subsubsection{Innovation capability behind the world technology frontier}

To capture innovation capability related to technological activities behind the world technology frontier, we calculate the mathematical difference between the priority filings count and the transnational patent applications count ${ }^{6}$.

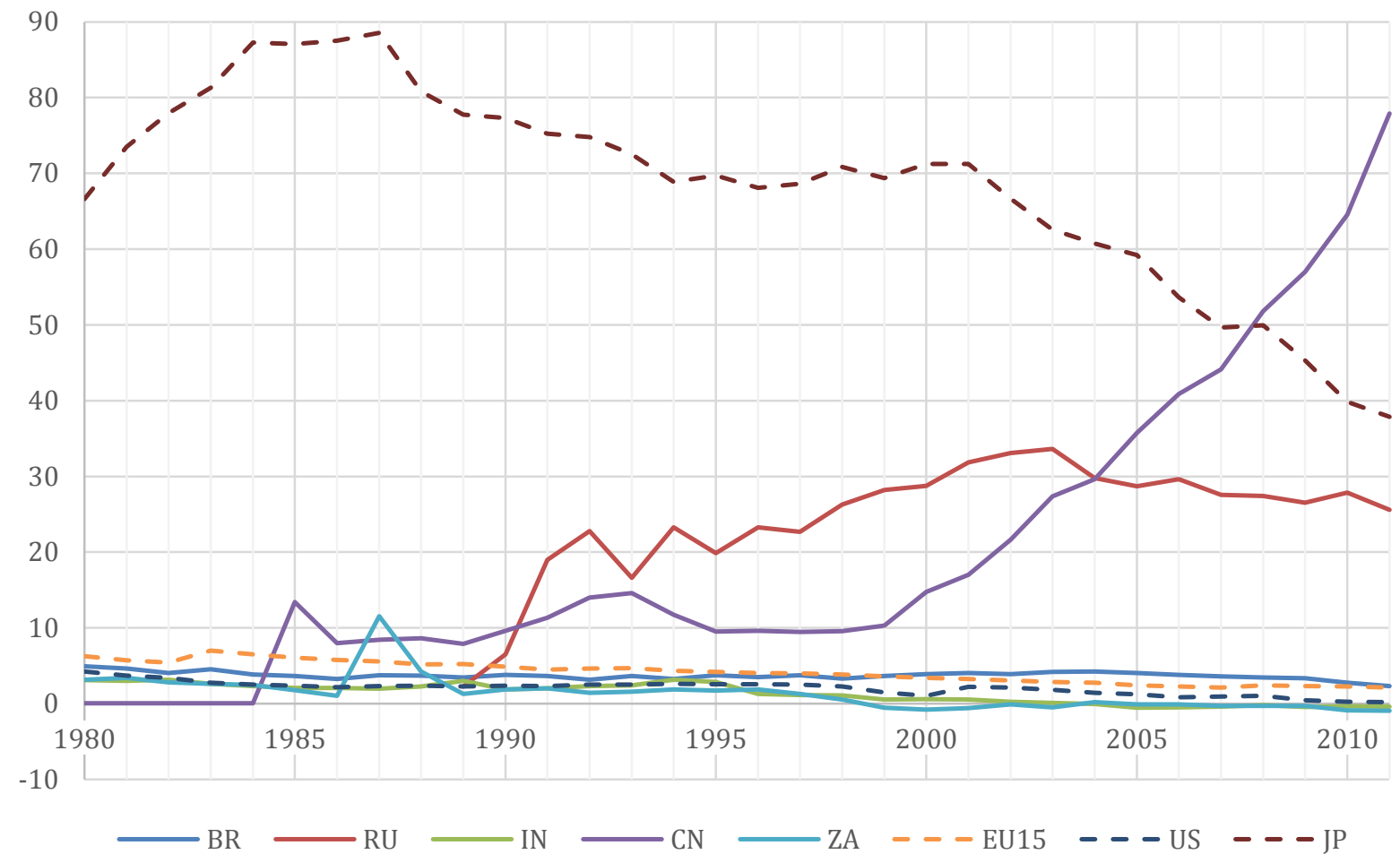

Source: Indicators elaborated by the authors using data from PATSTAT and World Bank.

\footnotetext{
${ }^{6}$ For South Africa (1999-2011) and India (2004-2011) this difference is negative due to two factors: first, differences in the timing of patent publications and their types, second, missing country codes for some data in PATSTAT (De Rassenfosse et al. 2013, p. 723). The shares of negative values in total priority patents for India and South Africa are $10.7 \%$ and $9.4 \%$ respectively. However, this margin of error in data does not change our conclusions for these two economies.
} 
Figure 2 shows the resulting count per unit of output (1 billion US\$ in constant prices 2005) for emerging and advanced economies per priority year (see Annex Table A2). Since the 1990s Russia and China have increased their intensities of behind the frontier activities substantially. In the first half of the first decade of the $21^{\text {st }}$ century China even surpassed the level of Japan. It is important to note that the intensities in behind frontier technologies stayed very low and flat during the whole observation period, not only for the other BRICS economies, but also for the US and EU15 economies. The relationship between technology frontier and behind frontier technology effort can be better visualised on a scatter diagram (see Figure 3).

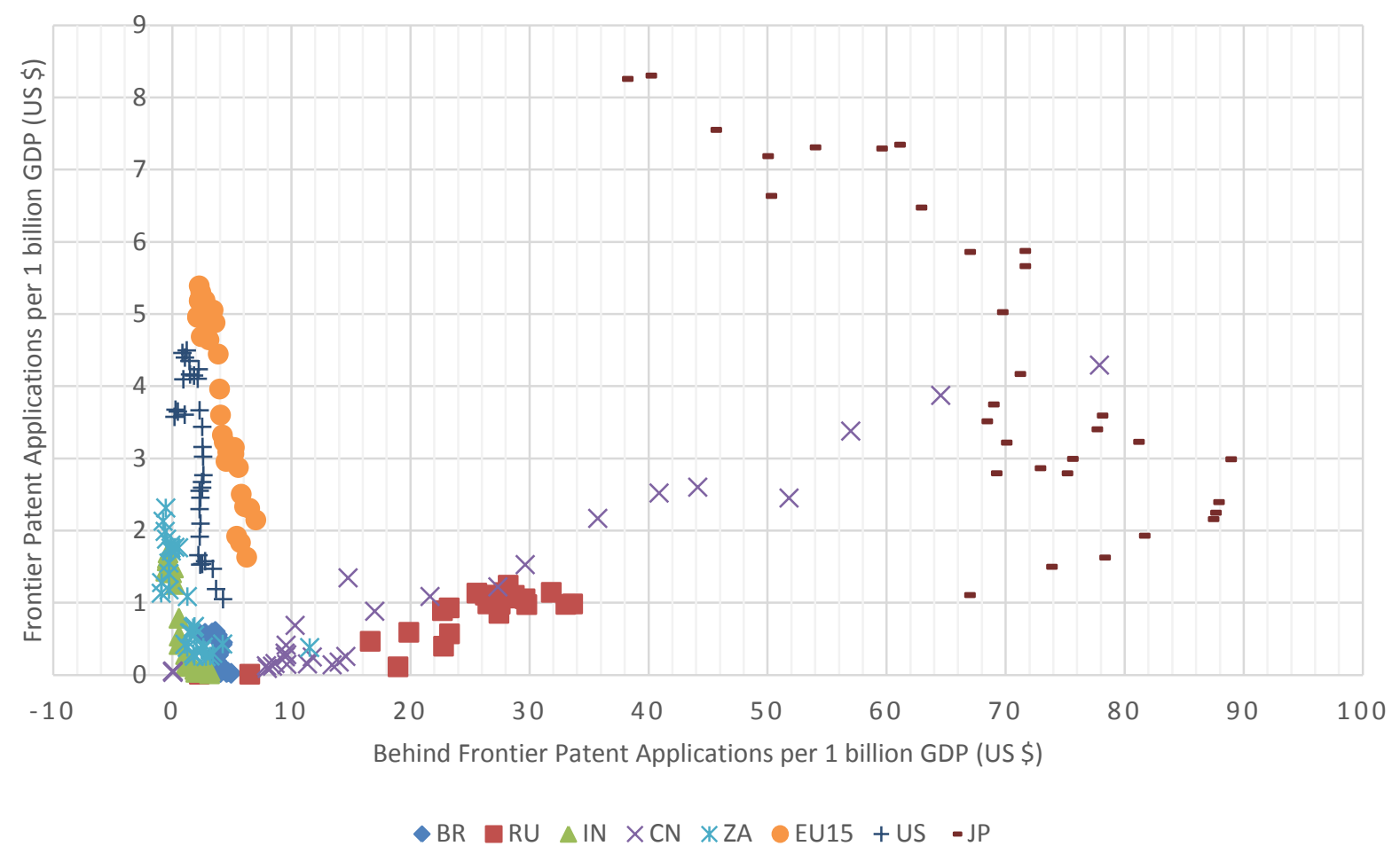

Source: Indicators elaborated by the authors using data from OECD REGPAT, PATSTAT and the World Bank.

Figure 3: Frontier and Behind Frontier patent applications over GDP (1 billion US\$ in constant prices 2005) during 1980-2011

There are four key messages from this analysis: First, the increase of patent intensity of GDP of the US and EU15 came entirely due to an increase in technology frontier activities. Second, this 
applies also to Japan, which shows a very distinct institutional bias towards high intensities of behind the frontier activities. Third, both Russia and China have substantially increased patent intensity of their GDP by pursuing both behind and at the technology frontier activities. However, the Chinese dynamics is superior as the increases in both types of effort (at the technology frontier and behind) seem to complement each other. Simple regression suggests that a $10 \%$ increase in priority patents intensity leads to a $0.5 \%$ increase in transnational patent intensity of GDP. For Russia, the dynamics of mutually supportive growth falters very early in the observation period, but it still shows extensive behind the technology frontier activities. Fourth, Brazil, India and South Africa are characterised by moderate growth of technology frontier activities and almost no growth of behind the frontier activities, which differs from the trends observed for China and Russia. This is most likely related to institutional differences related to the technological openness of the different BRICS rather than very low innovation capabilities, since the BRICS economies (except for China) are comparable regarding technology frontier patenting (Figure 1).

In sum, high-income countries (EU15, US and Japan) are more engaged in frontier technologies compared to all BRICS economies. In the most recent period only China has managed to increase the scale of technological frontier activities to the levels observed in high-income countries. The other BRICS economies did not reduce the gap in frontier activities to highincome economies. China and Russia have been able to catch up with high-income countries in terms of behind the frontier activities. This does not apply to India, South Africa and Brazil. Our evidence supports hypothesis one on the observation that middle-income countries accumulate innovation capabilities moderately while high-income economies are characterised by strong innovation capabilities at the technology frontier. 


\subsection{BREADTH OF TECHNOLOGY UPGRADING}

To analyse the breadth of technology upgrading, we focus on the features of structural change in the technological knowledge base. We define two structural change indicators to measure (i) the shifts in knowledge intensity of technological activities and (ii) the diversification of the technological activities.

\subsubsection{Knowledge intensity}

We calculate the share of patent applications in high technology fields and knowledge-intensive services $^{7}$ (HKTI) in all transnational patent applications with at least one domestic applicant for the period 1980-2011 (see Figure 4) (see Annex Table A2). We consider HTKI patents as an indicator of 'knowledge intensity of technological activities' or proxy for 'dynamic technology frontier activities'.

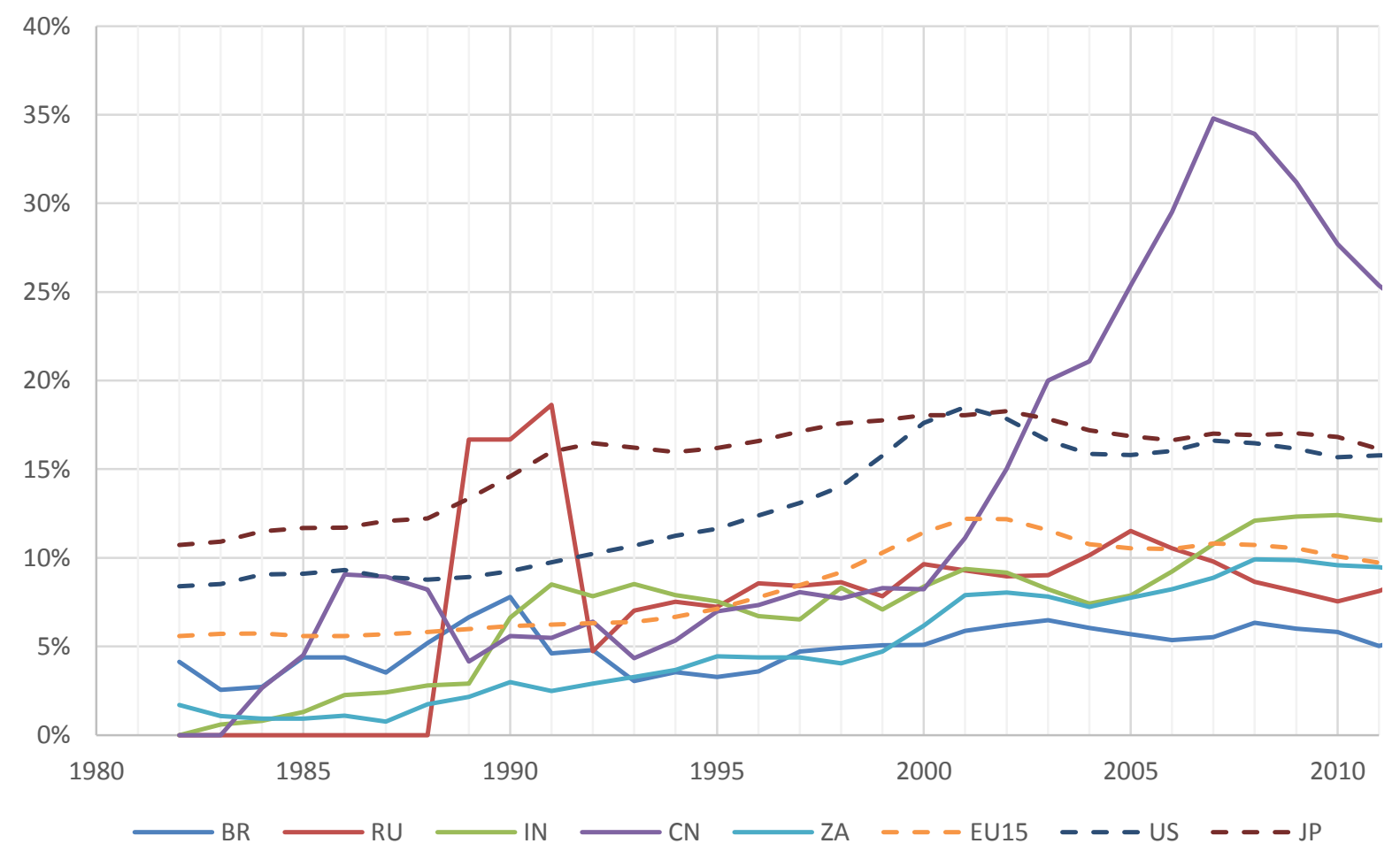

Source: Indicators elaborated by the authors using data from PATSTAT. (see footnote 6)

\footnotetext{
${ }^{7}$ We follow the EUROSTAT definition of high tech activities (last accessed 13.01.2015): HYPERLINK "http://ec.europa.eu/eurostat/cache/metadata/Annexes/htec_esms_an6.pdf" http://ec.europa.eu/eurostat/cache/metadata/Annexes/htec esms an6.pdf
} 
Figure 4: Share of high technology and knowledge-intensive fields in transnational patents (3-Year moving averages - MA) (in\%)

Figure 4 shows that the US and Japan have a high share of high technology fields and knowledge-intensive services. The relatively low share of the EU15 compared to the US/Japan reflects differences in industry structure (Moncada-Paternò-Castello et al., 2016). Since the 1990s the BRICS have experienced irregular and moderate growth in the share of high-tech and knowledge-intensive activities. China, India, and to a lesser extent South Africa, show increased rates in the 2000s. In the case of China, we witness a remarkable structural change towards dynamic technology frontier activities, which started at the end of the 1990s. Today China has the highest share of HKTI patents in transnational patents and has surpassed the levels observed in the high-income countries. This could signal the entry of China into particular 'dynamic frontier activities' with potentially positive effects for the observed increases in the scale of frontier activities.

The indicators seem to support our second hypothesis with regard to the increasing knowledgeintensity of innovation capability, as countries move from middle-income to high-income economies. The BRICS economies have consistently lower but gradually growing shares of hightech and knowledge-intensive patents in their overall frontier technology compared to the high-income countries (US, and Japan) throughout the observation period.

\subsubsection{Technology diversification}

To measure the general diversification of technological knowledge we select a proxy proposed by Lee (2013). We count the number of IPC subclasses (in total 639 fields) ${ }^{8}$ in which each country filed transnational applications during the period 1980 to 2011 (see Annex Tables A1 and A2). China has been diversifying into different technological fields in frontier activities

\footnotetext{
${ }^{8}$ Lee (2013) uses USPTO data and the US patent classification system to define the 417 fields (3-digit USPC codes).
} 
(measured with transnational patents) since the mid-1980s (see Figure 5). Most recently China has converged to the levels of diversification observed for high-income countries. Russia had a clear diversification trend in the 1990s that slowed down afterwards to develop at a similar path as in Brazil and India. Even though India and Brazil had steady diversification since the 1990s, their levels of diversification have not converged to the diversification structure observed for the high-income countries. Finally, South Africa still holds a much narrower and stable domestic knowledge base ${ }^{9}$.

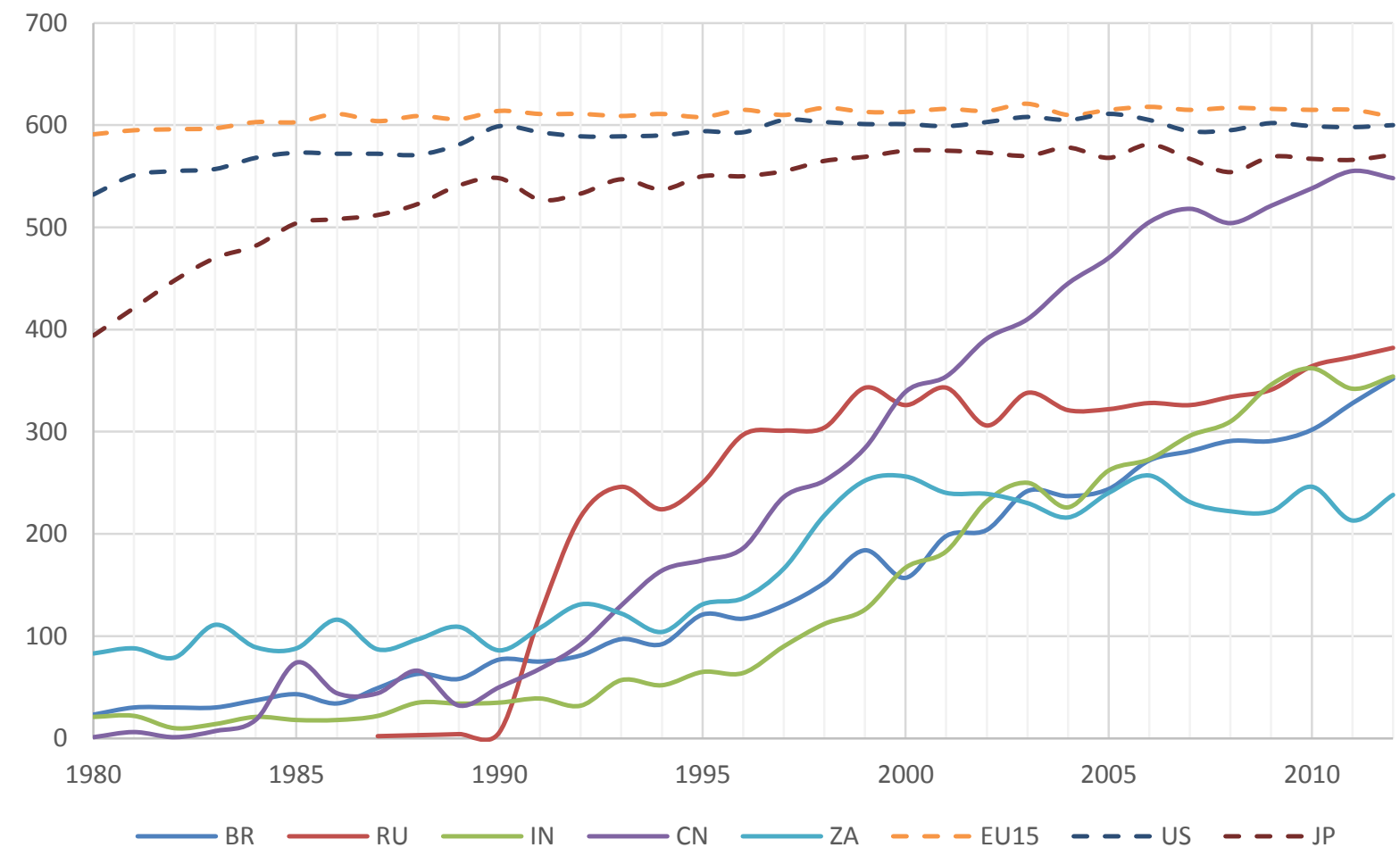

Source: Indicators elaborated by the authors using PATASTAT. * max. IPC subclasses $=639$

Figure 5: Number of technological fields (IPC subclasses)* used in transnational patents per priority year

\footnotetext{
${ }^{9}$ We have also used the Herfindahl index of all transnational patent applications with domestic inventors across 35 countries and 639 technological fields during the period 1980 to 2011 as the proxy for structural change. However, we do not include this analysis, as results are much less persuasive than simple counts of IPC subclasses. We followed a methodology proposed by Schmoch (2008) to classify patents in different technology fields. These data (available upon request) suggests that long term diversification in both China and India are also present though less discernible.
} 
In sum, the evidence supports hypothesis three; that middle-income countries are in the process of diversifying their domestic technological knowledge, while high-income economies already possess a diversified technological knowledge structure. However, it seems important to note that we also observe middle-income countries such as South Africa, which have slowed down their diversification in frontier activities.

\subsection{GLOBAL INTERACTION}

Patent indicators also allow us to trace international knowledge flows in technological activities. Guellec and van Pottelsberghe $(2001,2010)$ develop the concept of 'cross-border ownership' to identify patents where inventors and patent applicants are located in different countries. Cross-border ownership is relevant in the context of technology upgrading because technological inventive activity is not of economic relevance unless organisational capabilities exist for exploiting or protecting the invention. For Teece (1986) these capabilities are 'complementary assets'. In the context of patent protection, inventors and applicants can be seen as holders of different assets that are combined through global interaction if they are located in different countries. From the perspective of technology upgrading cross-border ownership leads to interesting interpretations. We use three indicators using this concept: First, we use foreign applications of native inventions (FANI) to measure the extent to which the exploitation of frontier technology in an emerging country is driven by foreign actors. Second, we use international co-inventions (COINV) in frontier technological activities to measure international technological collaboration. Third, we consider native applications of foreign inventions (NAFI) as a proxy for the extent to which frontier activities of emerging economies are based upon technology sourcing from abroad (see Annex Tables A1 and A2). We interpret these indicators not only for direction of knowledge flows but also as proxies for the origin of the complementary assets. 


\subsubsection{Foreign applications of native inventions}

Following Guellec and van Pottelsberghe $(2001,2010)$, we compute the share of transnational patent applications with at least one inventor ${ }^{10}$ located in the respective country and an applicant located abroad. Counting transnational applications per priority year, the number of transnational patents applied by foreigners and invented by natives (FANI) is divided by the total number of transnational patents with at least one national inventor to calculate the 'FANIRate' (see Annex Tables A1 and A2). We calculate the FANI-Rates for the countries under investigation in the period 1980 to 2011 (see Figure 6). A high FANI-Rate on transnational patents suggests a relatively high importance of foreign actors for the exploitation of frontier technology in the respective economy and low organisational capabilities to exploit the knowledge. A low FANI-Rate suggests relatively high organisational capabilities of domestic players to commercialise their technological knowledge and vice versa.

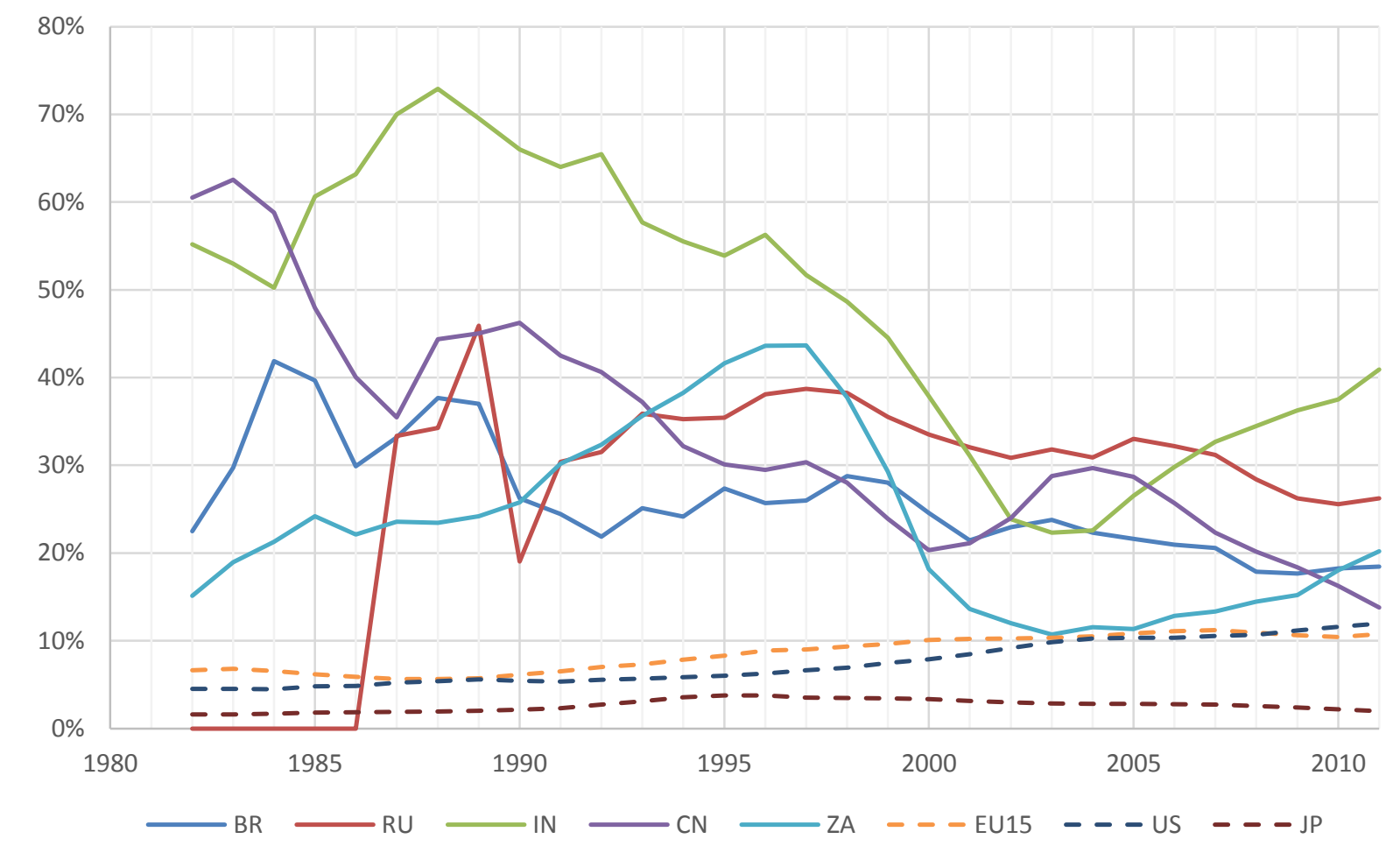

\footnotetext{
${ }^{10}$ If an application involves inventors from different countries the national assignment will be a fractional count.
} 
Source: Indicators elaborated by the authors using REGTAT.

Figure 6: FANI Rate for transnational patents per priority year (3-year MA)

Our data suggest clear differences between high-income and BRICS economies (see Figure 7). High-income countries are characterised by low levels of FANI-Rates which suggest the dominant importance of domestic actors for the generation of frontier technology and the prevalence of complementary assets in the group of high-income countries. Throughout the observation period Japan had the lowest FANI-Rates that stands today at only $2 \%$, which reflects still very much domestically-controlled technology development. FANI-Rates have been increasing slightly, especially for the US and EU15, which reflects increasing internationalisation of R\&D within the group of high-income economies. In the initial phase, all BRICS economies relied heavily on foreign actors to exploit frontier technologies. At the beginning of the observation period, FANI-Rates stood at up to $70 \%$ in BRICS. Today the rates have fallen dramatically, but still to levels above the FANI-Rates observed for the high-income economies. Interestingly, there are considerable differences within the BRICS, where India has currently the highest FANI-Rate (about 41\%) and China the lowest FANI-rate (about 14\%). This suggests that complementary assets to exploit their inventions have increased in China but not in India.

These insights broadly support our hypothesis $\mathrm{H} 4$ which proposes that middle-income economies show an increasing relative importance of domestic actors in frontier technologies, while in high-income economies the generation of frontier technology is mainly based on domestic actors. However, we need to recall that, in this phase, the overall level of frontier activities in these large emerging countries was very low. Over time, and with slowly increasing scales of frontier activities, the relevance of foreign actors and international collaboration relatively (not absolutely) decreases. 


\subsubsection{International co-inventions}

Again, we follow Guellec and Pottelsbergue's $(2001,2010)$ method to measure international collaboration using counts of transnational patent applications with inventors residing in different countries. Our indicator is the share of transnational patent applications resulting from international technological co-invention in the total number of patents by inventors located in a given country (COINV-Rate) (see Annex Tables A1 and A2). A high COINV-Rate reflects a high importance of international collaboration in the generation of frontier technology. Below we present the COINV-Rates for the countries under investigation in the period 1980 to 2011 (see Figure 7).

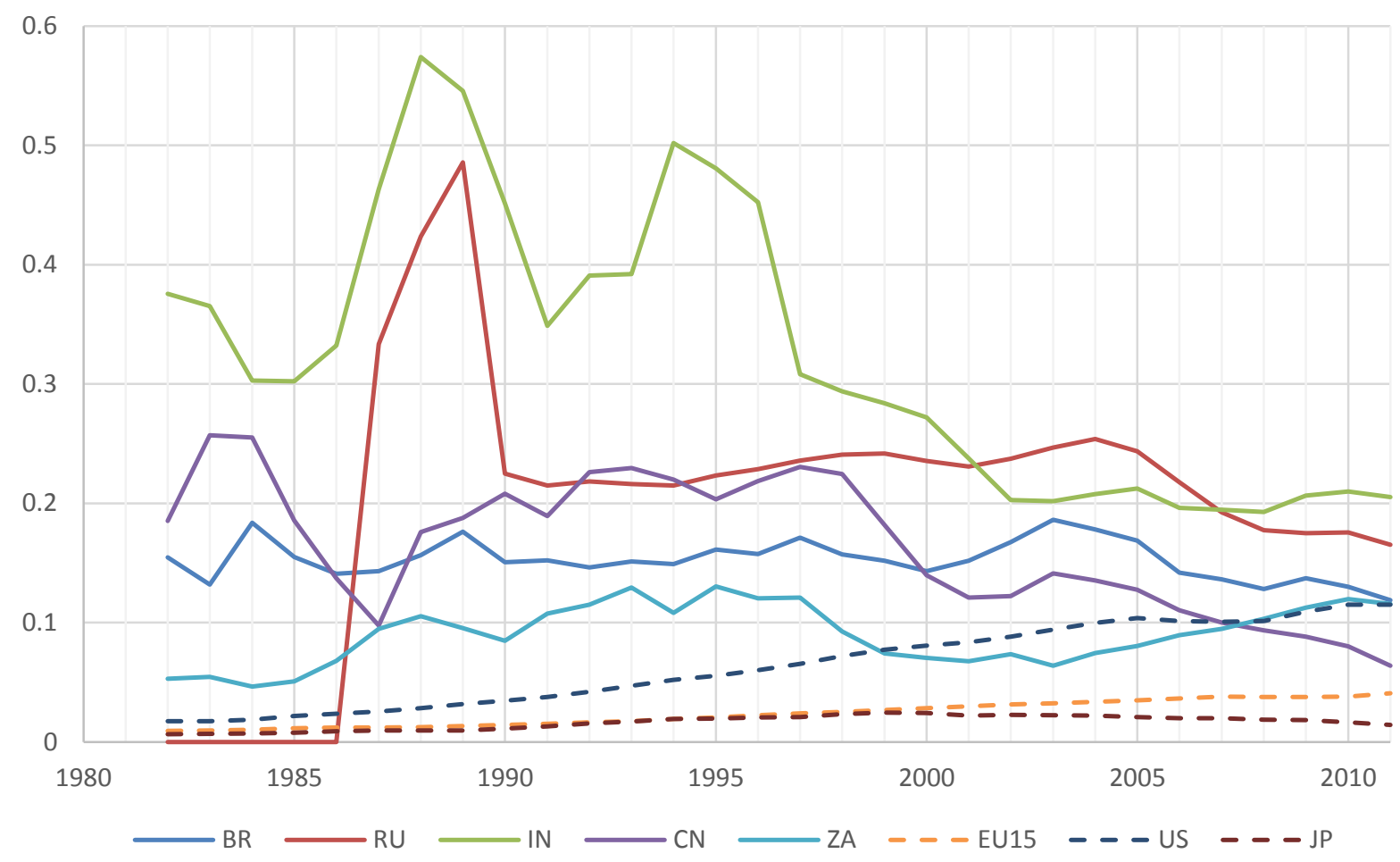

Source: Indicators elaborated by the authors using REGTAT.

Figure 7: Co-Invention Rate for Transnational Patents per priority year (3-year MA)

First, we observe significantly different levels of co-invention between BRICSs and the highincome economies, which have been reduced in the last two decades. Second, the intensity of 
co-invention in high-income economies, especially in the US, has slightly increased reflecting globalisation of R\&D but, at the same time, has been reduced in BRICS. This relative reduction in co-inventions can be interpreted as reduced dependence of BRICS on technology transfer. This is particularly strong in the case of China whose COINV-Rate dropped below the rate observed for the US. In sum, these trends are in line with our hypothesis four. For BRICS economies international collaboration is still relatively important for frontier technology activities compared to major high-income economies. Nonetheless, the engagement in coinvention activities is quite variable among BRICS, suggesting different dependency degrees on technology transfer to develop frontier technologies as well as the various international strategies in their technology upgrading process.

\subsubsection{Native Application of Foreign Inventions}

Native applications of foreign inventions are a proxy for the extent to which an emerging economy is exploiting inventions in frontier technology sourced from abroad. Following Guellec and van Pottelsberghe $(2001,2010)$ we count the transnational patent applications with an applicant located in a selected country that involve at least one inventor located abroad (NAFI). The indicator (NAFI-Rate) is calculated by dividing NAFI by the total number of transnational patents with at least one national applicant in the period 1980 to 2011 (see Annex Tables A1 and $\mathrm{A} 2$ ). A relatively high NAFI-Rate indicates that a large share of technologies protected and exploited by home actors are based on foreign inventions. This reflects increasing organisational capabilities or building up of complementary assets by domestic firms (Teece, 1986). 


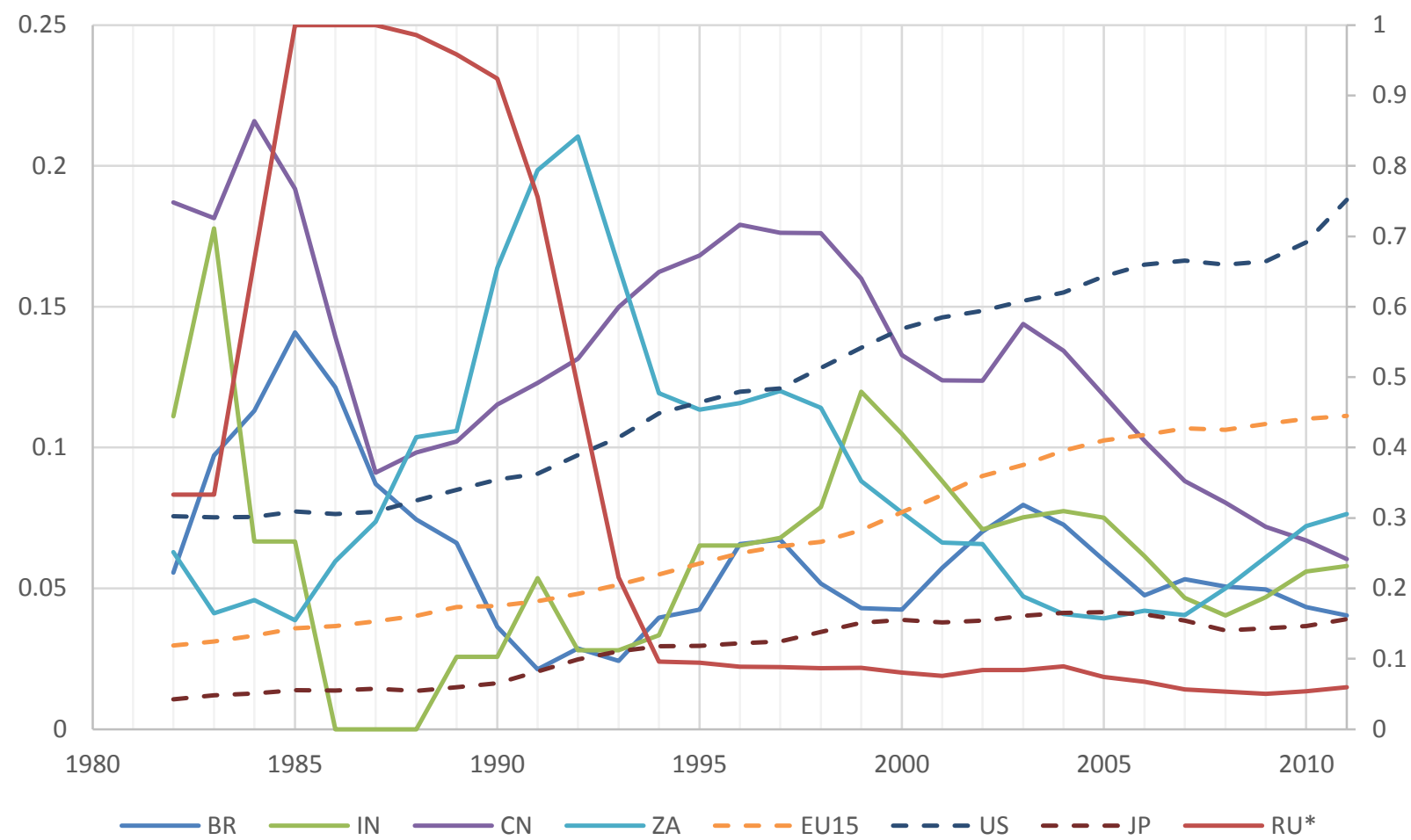

Note: *Figures for RU are given on secondary axis.

Source: Indicators elaborated by the authors using REGTAT.

Figure 8: NAFI Rate for Transnational Patents per priority year (3-year MA)

NAFI-Rates have been at about $5 \%$ to $20 \%$ for BRICS economies at the start of the observation period. At this stage we also observed very low overall levels of transnational patents (see Figure 8). NAFI-Rates declined to levels below the ones observed for the US and EU15 over time. The NAFI-Rates of all high-income economies under investigation have been gradually increasing as a sign of increasing technology sourcing from abroad and organisational capabilities. Again, Japan shows a pattern, which is distinct from the other high-income economies, with a relatively low NAFI-Rate (4\%) in comparison to the EU15 and US. Today NAFI-Rates of BRICS economies are between 1\% (Russia) and 8\% (South Africa), whereas we observe $11 \%$ and $19 \%$ for the EU15 and US respectively. 
These differences are in line with our hypothesis four, suggesting that the organisational capabilities of middle-income economies to source technology from abroad is significantly lower when compared to high-income countries (with the exception of Japan).

\subsection{AN INTEGRATED PERSPECTIVE}

In this and the following section, we integrate all three dimensions to explore levels and patterns of changes of technology upgrading over time. Figure 9 and Figure 10 include all seven indicators investigated above: frontier technological intensities; behind the frontier technological intensity; the share of high-tech and knowledge-intensive transnational patent applications in total transnational patent applications (High tech patents); and the level of diversification in transnational patents $\left(D I V_{-} T N\right)$. Global interaction is represented by the FANIRate, the COINV-Rate and the NAFI-Rate.

Figure 9 includes network diagrams for the periods 1988-1995 and 2004-2011 for BRICS, EU, USA and Japan. The values for the indicators in each period are the average of the annual values in each period. The network diagram provides for each indicator the relative position of each economy to the economy with maximum value for each indicator. 

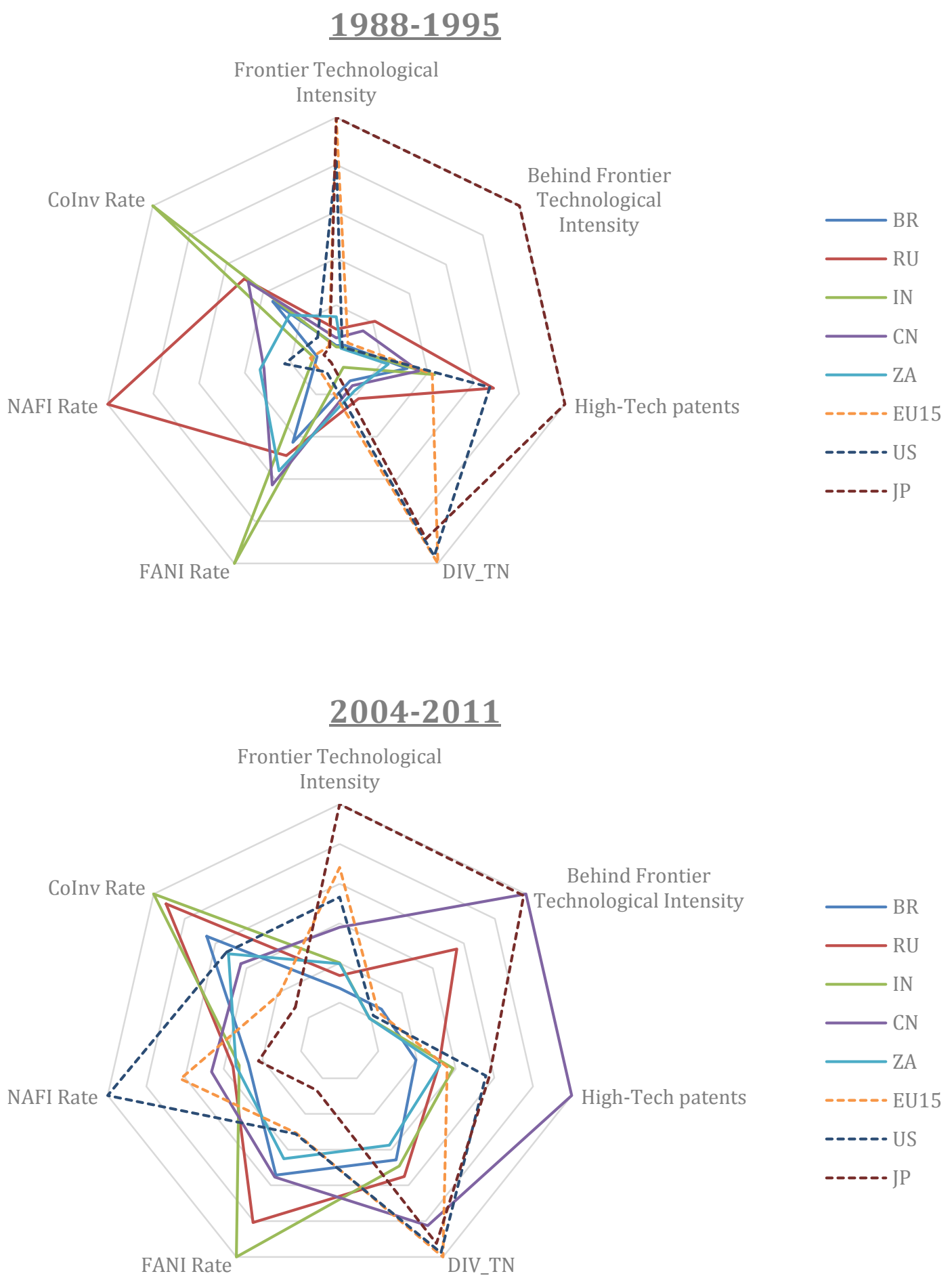

Note: Values of each indicator scaled between 0 and 1 across BRICS, US, EU15 and Japan in each period. Source: Indicators elaborated by the authors using data from PATSTAT, OECD REGPAT and World Bank.

Figure 9: Country profiles with relative indicators in the periods 1988-1995 and 2004-2011*

In the period 1988-1995 high-income economies lead BRICS economies in terms of technological intensity at the frontier and behind the frontier (in the latter case only Japan). 
This applies also to high-tech patents (except for the EU15 in this case) and to the diversification of technological knowledge base ${ }^{11}$. We find a relatively low global interaction of all economies in the period 1988-1995. In this period India is the only emerging economy with relatively high global interaction in terms of co-inventions and the relative importance of foreign actors in frontier activities (FANI-Rate) ${ }^{12}$. All in all, the integrated perspective in the period 1988-1995 suggests a clear latecomer position of BRICS. In the second period (20042011) BRICS have upgraded technologically but at different levels and following different paths. To analyse this upgrading process, we now focus on the BRICS profiles only and on the changes in the respective indicators over time.

\subsection{BRICS technology upgrading profiles in 1988-1995 and 2004-2011}

Please note that we now rescale the indicators only across BRICS economies for each period. In the period 1988-1995 (see Figure 10), Russia had a distinctive profile characterised by comparatively high technological intensity and by the highest share of high-tech and knowledge-intensive frontier activities among BRICS. South Africa still had a leading position regarding frontier activities, jointly with Russia $^{13}$. All BRICS economies showed fairly similar levels of low diversification across technological fields. Brazil had the lowest degree of global interaction, whereas India was relatively more engaged in co-generation of patentable knowledge compared to other BRICS economies. Overall, in the period 1988-1995 technology upgrading profiles of BRICS show unexpected homogeneity, which reflects their limited

\footnotetext{
${ }^{11}$ A high share of high-tech patents and high NAFI rate for Russia in this period should be ascribed to small number of TN patents and to turbulent economic period.

${ }^{12} \mathrm{~A}$ high NAFI rate for Russia is aberration reflecting very low values and idiosyncrasies of the late socialist and early transition period.

${ }^{13}$ This may seem puzzling as both economies for different reasons were closed economies during the 1980s. This status has forced the, to very often not only 'reinvent the wheel' i.e. innovate behind the barrier but it also pushed them to invest more in R\&D as a way to compensate for difficult access to technology.
} 
involvement in technology frontier activities and (with the exception of India) also a low degree of integration with the global economy at the time.
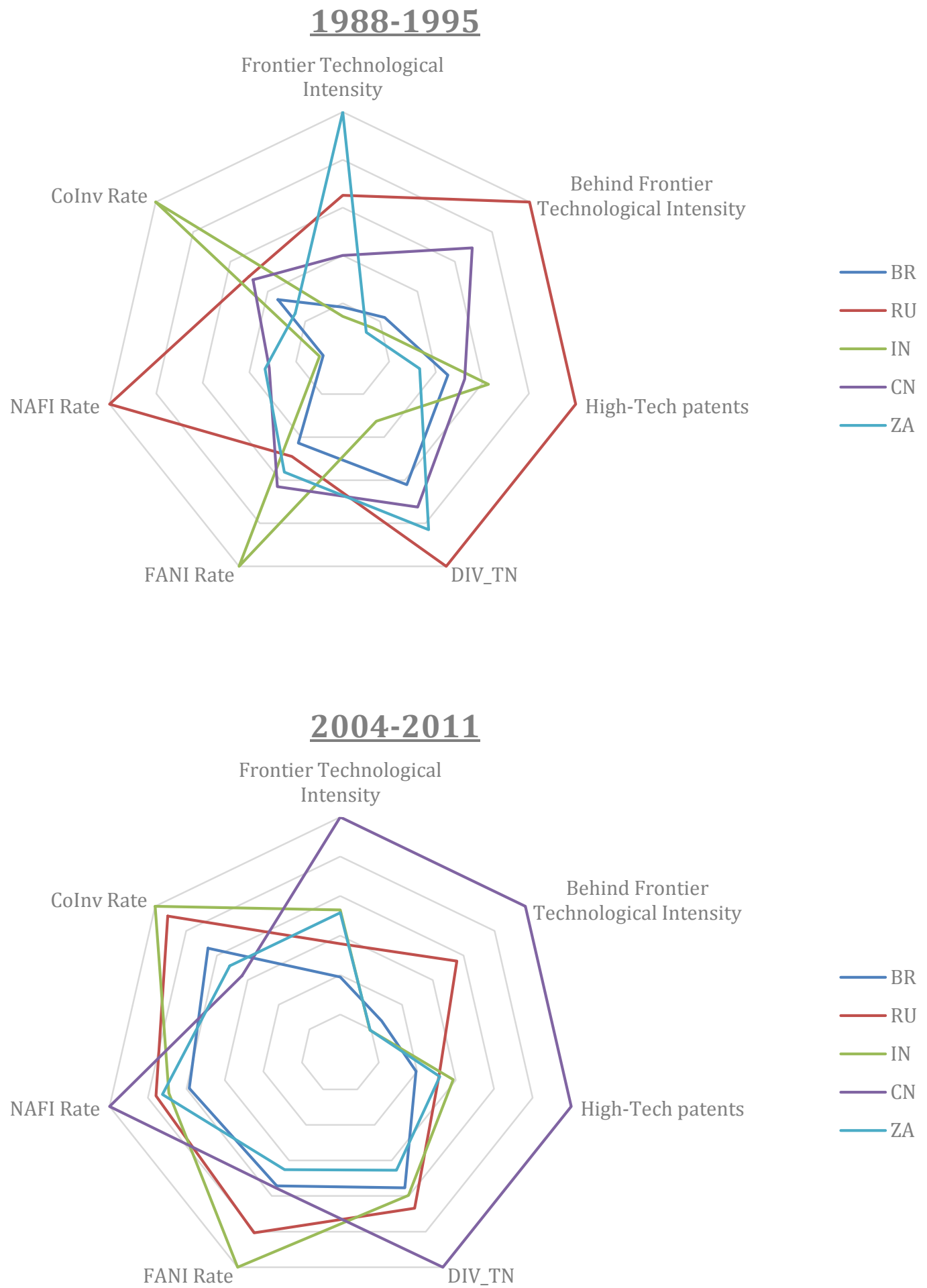

Note: Values for each indicator scaled between 0 and 1 across BRICS within each period. Source: Indicators elaborated by the authors using data from PATSTAT, OECD REGPAT and World Bank. 
In the period 2004 to 2011, the relative positions had changed considerably. China has practically delinked from the BRICS group by its largely increased scale of behind the frontier and frontier technological activities, a very high share of patents in high-tech areas, as well as a high position in terms of diversification of the technological knowledge base. This reflects an increasing scale of technological activity as well as structural change. Simultaneously, the relative importance of foreign actors and international collaborations in frontier activities has been reduced to very low positions. This indicates strong domestic-led technology modernisation of China coupled with the strategic use of technology cooperation and sourcing of foreign knowledge. To some extent, India moved into the opposite direction i.e. it enhanced foreign-led technology modernisation. It could not improve its relatively low position in terms of the scale of domestic and frontier technological activities and scored very low in dynamic frontier activities (high-tech patents). At the same time, India continued to be relying on foreign actors and on international collaboration for its frontier activities. Russia lost its leading position among BRICS in behind the frontier and frontier technologies as well as in dynamic frontier activities. It kept a relatively high degree of diversification, but its reliance on foreign actors and international collaboration in frontier activities was comparatively high (though below the Indian levels). South Africa also underwent dramatic changes, since the country lost its leading position in frontier technology and did not substantially diversify (in terms of overall knowledge base as well as dynamic frontier activities). A particularity seems to be the relatively high rate of technology sourcing from abroad for frontier activities. However, a relatively large technology sourcing was not coupled with behind the frontier technology activities and thus seems to be of limited impact and as a substitute rather than a complement to frontier activities. The Brazilian case of technology upgrading is special in respect to very few changes in 
the three dimensions. It kept its relatively high level of general diversification, but did not substantially increase the scale of behind the frontier and frontier activities. Brazil has also been characterised by limited levels of global interaction in both periods.

To analyse the upgrading process further, we calculate the changes in the values of the indicators of technology upgrading between the two periods for each BRICS individually (see Table 1).

\begin{tabular}{|l|l|l|l|l|l|l|l|l|}
\hline & $\begin{array}{l}\text { Frontier } \\
\text { intensity }\end{array}$ & $\begin{array}{l}\text { Behind } \\
\text { Frontier } \\
\text { intensity }\end{array}$ & $\begin{array}{l}\text { High- } \\
\text { Tech } \\
\text { Patents }\end{array}$ & $\begin{array}{l}\text { Diversifi } \\
\text { cation }\end{array}$ & $\begin{array}{l}\text { FANI- } \\
\text { Rate }\end{array}$ & $\begin{array}{l}\text { NAFI- } \\
\text { Rate }\end{array}$ & $\begin{array}{l}\text { COINV - } \\
\text { Rate }\end{array}$ & $\begin{array}{l}\text { TU } \\
\text { index* }\end{array}$ \\
\hline India & $2123 \%$ & $-115 \%$ & $66 \%$ & $593 \%$ & $-42 \%$ & $24 \%$ & $-54 \%$ & $371 \%$ \\
\hline China & $1419 \%$ & $360 \%$ & $413 \%$ & $423 \%$ & $-49 \%$ & $-44 \%$ & $-58 \%$ & $352 \%$ \\
\hline Brazil & $527 \%$ & $-3 \%$ & $15 \%$ & $238 \%$ & $-26 \%$ & $25 \%$ & $-13 \%$ & $109 \%$ \\
\hline Russia & $234 \%$ & $77 \%$ & $-16 \%$ & $153 \%$ & $-4 \%$ & $-87 \%$ & $-16 \%$ & $49 \%$ \\
\hline S. Africa & $214 \%$ & $-117 \%$ & $158 \%$ & $108 \%$ & $-53 \%$ & $-61 \%$ & $-7 \%$ & $34 \%$ \\
\hline
\end{tabular}

Note: *simple average change rate of the seven indicators

Source: Indicators elaborated by authors using data from OECD REGPAT, PATSTAT and World Bank.

Table 1: Changes in indicators and aggregate technology upgrading index 2004-11/1988-1995 (in \%)

The aggregate index of technology upgrading (TU Index) is the simple average of seven indicators of technology upgrading which enables us to compare differences in degrees of technology upgrading among BRICS. It is not surprising, based on the evidence so far, that India and China are the economies with by far the highest degree of change in their technology upgrading followed at some distance by Brazil, Russia and South Africa. China is well ahead of India regarding levels of technology upgrading, but India is catching up. The most intensive and common changes among BRICS were in frontier technology intensity and diversification of the technological knowledge base. In all other dimensions, the intensity of changes between the 
end of the 1980s/early 1990s and the current period are much smaller and divergent. The behind the frontier technological intensity increases in China and Russia, but decreases in other BRICS economies. However, the most interesting result is changes in all three indicators of global interaction which have declined between the two periods. Earlier analyses showed the dependencies of BRICS on foreigners for exploiting their technological capabilities (as captured by the FANI indicator). Also, they still have limited capabilities in technology sourcing abroad (NAFI Rate) (see Figures 6-8). However, the data in Table 1 shows that these dependencies are gradually being reduced..

\section{DISCUSSION AND CONCLUSIONS}

Based on the conceptualization of technology upgrading as the three-dimensional process, we explored different paths of technology upgrading of the BRICS economies. We differentiate between the intensity of technology upgrading as depicted by different types and levels of innovation capabilities, the extent of technology upgrading in terms of changes to the structure of technological knowledge, as well as the role of global interaction in terms of inflows of foreign technology and coupling with domestic technological efforts.

We have formulated five general hypotheses on the characteristics of technology upgrading of middle-income economies such as BRICS. We have applied this three-pronged approach to technology upgrading by using different patent indicators to test these hypotheses. Our evidence shows that hypothess one and three have been confirmed in the case of the BRICS economies, since the generic trends are increased technology intensity reflected in the accumulation of innovation capability (hypothesis one) and increased diversification of technological knowledge (hypothesis three). Hypothesis two on changes in the structure of technological knowledge (captured by the increasing proportion of high-tech and knowledgeintensive patent applications) has been confirmed in all BRICS apart from Russia. 
As part of the analysis of technology intensity, we have explored the relationship between innovation capability pushing the technological frontier and innovation capability behind the world technology frontier. All BRICS have increased frontier technology activities. However, we find that increased or stable share of behind the frontier intensity has been present only in the case of China, Russia and Brazil while it seems that in other BRICS available foreign knowledge substitutes for domestic technology effort. This shows that the relationship between frontier and behind frontier technology activities is country specific and reflects the nature of modernisation of the individual BRICS economy and how it interacts with the globalisation processes.

Hypothesis four refers to global interactions in the process of technology upgrading and to the role of organisational capabilities.. It assumes that as countries' incomes grow and technological capabilities upgrade, they can move from the stage where foreigners have an important role in protecting and exploiting the commercial potential of national inventions into a process of knowledge co-generation and technology sourcing from abroad. Indeed, our evidence shows that before the globalisation of the 1990s/2000s, BRICS economies showed a relatively high dependence on foreign actors in their frontier activities when compared to advanced economies. This dependence decreases over time. Also, the relative (not absolute) reduction in international co-inventions is interpreted as reduced dependence of BRICS economies in technology transfer. In this respect, differences among BRICS are quite significant suggesting different dependency degrees on technology transfer to develop frontier technologies, as well as the various international strategies in their technology upgrading process.

BRICS economies have improved their technology sourcing capabilities, but we do not yet see catching up in that respect or an increase in their organisational capabilities to source 
technology from abroad. These results suggest some degree of caution is needed, regarding the relevance of technology seeking strategies for outward FDI by emerging market firms as emphasised in recent firm level investigations (see, for example, Mathews, 2006; Li, 2010; Ramamurti, 2012; Narula, 2012; Jindra et al. 2016). Overall, trends in global interaction suggest that organisational capabilities or complementary assets of the BRICS economies are still significantly low when compared to the US and EU15. In that respect, our hypothesis four has not been fully confirmed.

The novelty of our inquiry is not only in the depiction or trends and ranking of BRICS but in a better understanding of the profiles of their technology upgrading over time which, in turn, can help us understand prospects for their long-term growth. Hypothesis five suggests that interaction among the proposed three dimensions of technology upgrading will lead to nationally specific paths and profiles of technology upgrading. The evidence shows that there is no single path of technology upgrading within the group of BRICS economies. Instead, we find several unique profiles of technology upgrading with different trade-offs between intensity, structural change and nature of interaction with the global economy.

China is unique among the BRICS economies in its scale of technological intensity (both behind and at the frontier), the very rapid improvements of the technological intensity, fast structural change in the direction of dynamic frontier activities, and technology diversification. The substantial increases of China in the intensity of frontier technological activities as well as the evidence of the diversification of technological knowledge in China seems to be similar to observations made by Lee (2013) for South Korea and Taiwan in earlier periods of successful and rapid technology upgrading.

At the same time China displays decreasing reliance on foreign actors in order to protect and potentially exploit its inventions. This also reflects increasing technology bargaining and 
difficulties between Chinese and foreign firms in ensuring the mutually beneficial sharing of gains from knowledge generation activities (Holmes at al., 2015). Yet, China has not yet reached a stage where it can engage in knowledge co-generation and technology sourcing at levels similar to advanced economies. This is also reflected in its dominance of behind the frontier technology intensity as compared to frontier technology intensity, where it still lags behind the high-income economies (in particular Japan). However, it is well ahead of other BRICS regarding terms of technology sourcing from abroad and corresponding organisational capabilities. The example of China suggests that there are dynamic complementarities between increased intensity, structural change and its specific modes of technology integration which also reflects its strong bargaining position in technology transfer.

India represents quite a different technology profile of technology upgrading when compared to China. It is much more technologically integrated when compared to China, as reflected in higher dependence on foreign actors and international collaboration in frontier activities, but very low technology sourcing from abroad. Its biggest difference when compared to China is not only lower frontier technology intensity but low behind the frontier technological intensity. This reflects a much more open technology system of India when compared to China. Although of very different nature, India's technology upgrading has improved most regarding frontier technology intensity and diversification of technology base and has further downscaled its behind the frontier technology effort.

Brazil represents the intermediate case in between the different paths of China and India and the non-dynamic paths of Russia and South Africa. Its technology frontier intensity has improved, and the structural change in the knowledge base seems to be heading in the direction as predicted by our hypotheses. However, its behind the frontier intensity has not increased significantly, which suggests the substitutive effect from its technology openness. 
Russia and South Africa display comparatively low dynamics with modest improvements regarding frontier technological intensity and increased breadth of technology upgrading (though less than India). The major difference between these two economies is that Russia (though much less than China) has grown the relative scale of behind the frontier technology activities which have all but disappeared in the case of South Africa. Similar to India, the behind the frontier technology intensity of South Africa has decreased, while in Russia it is the other way around. This suggests that the basis for the long-term technology-based growth of Russia and South Africa are not only more limited but are also qualitatively different.

Overall, our analysis has applied a new conceptual approach to exploring paths of technology upgrading of middle-income economies at the example of the BRICS economies. We have developed a new statistical framework which is suitable for exploring the extent to which different paths of technology upgrading represent the basis for long-term sustainable growth. Although being a multidimensional framework, it enables comparative analysis of technology upgrading while still retaining the link between indicators and the concepts. This should make our approach useful as an assessment tool to be used for policy purposes. Equally, it is conceptually and theoretically ambitious approach, which can be further developed theoretically.

The main limitation of our analysis is that it is based on hypotheses of a general nature, which are relevant for middle-income economies. These are tested on BRICS economies only and capture only innovation capabilities of technology upgrading but not R\&D and production capabilities. So our approach should be extended further by enlarging the scope of countries based on patents indicators and by extending the approach combining patents with other indicators. 


\section{Appendix}

Table A1 Overview of variables and measurement

\begin{tabular}{|c|c|c|}
\hline Variable & Measurement & Source \\
\hline \multicolumn{3}{|c|}{ Intensity of technology upgrading } \\
\hline $\begin{array}{l}\text { Innovation capability pushing } \\
\text { the world technology frontier } \\
\text { (TN) }\end{array}$ & $\begin{array}{l}\text { Number of transnational patent applications }{ }^{1} \text { per } \\
1 \text { billion GDP (in US\$ constant prices 2005) }\end{array}$ & $\begin{array}{l}\text { OECD REGPAT, } \\
\text { World Bank }\end{array}$ \\
\hline $\begin{array}{l}\text { Innovation capability behind } \\
\text { the world technology frontier } \\
\text { (B.-Frontier) }\end{array}$ & $\begin{array}{l}\text { Mathematical difference between the priority } \\
\text { filings }{ }^{2} \text { count and the transnational patent } \\
\text { applications count per } 1 \text { billion GDP (in US\$ } \\
\text { constant prices 2005) }\end{array}$ & $\begin{array}{l}\text { OECD REGPAT, } \\
\text { World Bank }\end{array}$ \\
\hline \multicolumn{3}{|c|}{ Breadth of technology upgrading } \\
\hline $\begin{array}{l}\text { Knowledge intensity of } \\
\text { technological activities (HTKI) }\end{array}$ & $\begin{array}{l}\text { Share of patent applications in high technology } \\
\text { fields }{ }^{3} \text { and knowledge-intensive services (HKTI) in } \\
\text { all transnational patent applications with at least } \\
\text { one domestic applicant (1980-2011) }\end{array}$ & PATSTAT \\
\hline $\begin{array}{l}\text { Diversification of the } \\
\text { technological activities (DIV) }\end{array}$ & $\begin{array}{l}\text { Number of IPC subclasses (in total } 639 \text { fields) in } \\
\text { which each country filed transnational } \\
\text { applications }\end{array}$ & PATSTAT \\
\hline \multicolumn{3}{|c|}{ Global Interaction in technology upgrading } \\
\hline $\begin{array}{l}\text { Extent to which the } \\
\text { exploitation of frontier } \\
\text { technology in an emerging } \\
\text { country is driven by foreign } \\
\text { actors (FANI-Rate) }\end{array}$ & $\begin{array}{l}\text { Number of transnational patents applied by } \\
\text { foreigners and invented by natives }{ }^{4} \text { (FANI) divided } \\
\text { by the total number of transnational patents with } \\
\text { at least one national inventor (FANI-Rate) }\end{array}$ & OECD REGPAT \\
\hline $\begin{array}{l}\text { International technological } \\
\text { collaboration (Co-Inv Rate) }\end{array}$ & $\begin{array}{l}\text { Share of transnational patent applications } \\
\text { resulting from international technological co- } \\
\text { invention (COINV) in the total number of patents } \\
\text { by inventors located in a given country (COINV- } \\
\text { Rate) }\end{array}$ & OECD REGPAT \\
\hline $\begin{array}{l}\text { Extent to which frontier } \\
\text { activities of emerging } \\
\text { economies are based upon } \\
\text { technology sourcing from } \\
\text { abroad (NAFI-Rate) }\end{array}$ & $\begin{array}{l}\text { Share of transnational patent applications with a } \\
\text { native applicant and at least one inventor located } \\
\text { abroad }^{4} \text { (NAFI) in the total number of } \\
\text { transnational patents with at least one national } \\
\text { applicant in the (NAFI-Rate) }\end{array}$ & OECD REGPAT \\
\hline
\end{tabular}

Source: Authors.

Notes:

1. Transnational patent applications are patents filed at the European Patent Office (EPO) or international patents filed under the Patent Cooperation Treaty (PCT), avoiding double counting. (Frietsch \& Jung, 2009)

${ }^{2}$. A priority filing is the earliest patent application in the patent family regardless the patent authority where it was filed. (De Rassenfosse et al., 2013)

${ }^{3}$. High technology fields and knowledge-intensive services (HTKI) are defined according to the EUROSTAT definition: (http://ec.europa.eu/eurostat/cache/metadata/Annexes/htec_esms_an6.pdf)

${ }^{4}$. FANI and NAFI indicators are defined based on (Guellec \& van Pottelsberghe, 2001) 
Table A2 Absolute values of indicators used along the paper (years 1980, 1990, 2000, and 2010)

\begin{tabular}{|c|c|c|c|c|c|c|c|c|c|}
\hline Yr. & Indicators & BR & RU & IN & CN & ZA & EU15 & US & JP \\
\hline \multirow{9}{*}{$\begin{array}{l}\text { \& } \\
\text { హ్ }\end{array}$} & Population(m) & 121.7 & 139.0 & 699.0 & 981.2 & 27.6 & 356.7 & 227.2 & 116.8 \\
\hline & GDP (b\$) & 513.4 & - & 204.0 & 217.5 & 147.1 & 7405.1 & 5927.3 & 2448.1 \\
\hline & Frontier (TN) & 10.6 & - & 11.6 & 7.3 & 38.3 & 12059.3 & 6207.1 & 2703.3 \\
\hline & B.-Frontier & 2535.0 & 188.1 & 631.4 & 11.0 & 466.0 & 46252.7 & 25238.1 & 163095.8 \\
\hline & HTKI & 0.8 & 0.0 & 0.0 & 0.0 & 1.0 & 775.7 & 664.2 & 318.8 \\
\hline & DIV & 23 & 0 & 21 & 1 & 83 & 591 & 532 & 394 \\
\hline & FANI-Rate & 0.341 & 0.000 & 0.655 & 0.591 & 0.178 & 0.061 & 0.047 & 0.016 \\
\hline & Co-Inv Rate & 0.246 & 0.000 & 0.309 & 0.045 & 0.048 & 0.009 & 0.019 & 0.006 \\
\hline & NAFI-Rate & 0.000 & 1.000 & 0.000 & 0.296 & 0.087 & 0.028 & 0.079 & 0.010 \\
\hline \multirow{9}{*}{ ㅇ్ㄱ } & Population(m) & 149.6 & 148.3 & 868.9 & 1135.2 & 35.2 & 366.0 & 249.6 & 123.5 \\
\hline & GDP (b\$) & 598.5 & 843.0 & 350.2 & 548.5 & 170.9 & 9421.5 & 8228.9 & 3851.3 \\
\hline & Frontier (TN) & 52.4 & 6.3 & 25.9 & 78.9 & 43.7 & 28215.6 & 20185.0 & 13095.3 \\
\hline & B.-Frontier & 2282.3 & 5483.0 & 662.2 & 5275.2 & 315.7 & 46107.9 & 19385.9 & 297772.4 \\
\hline & HTKI & 5.3 & 0.0 & 3.7 & 4.2 & 1.6 & 1968.6 & 2185.9 & 2323.7 \\
\hline & DIV & 77 & 6 & 35 & 50 & 86 & 614 & 599 & 548 \\
\hline & FANI-Rate & 0.186 & 0.194 & 0.691 & 0.445 & 0.257 & 0.067 & 0.053 & 0.023 \\
\hline & Co-Inv Rate & 0.144 & 0.217 & 0.411 & 0.207 & 0.086 & 0.015 & 0.036 & 0.013 \\
\hline & NAFI-Rate & 0.022 & 0.897 & 0.000 & 0.107 & 0.260 & 0.045 & 0.091 & 0.018 \\
\hline \multirow{9}{*}{ ষ্ণ } & Population(m) & 174.5 & 146.6 & 1042.3 & 1262.6 & 44.0 & 378.2 & 282.2 & 126.9 \\
\hline & GDP (b\$) & 769.0 & 567.4 & 602.7 & 1417.0 & 204.7 & 11866.2 & 11558.8 & 4308.1 \\
\hline & Frontier (TN) & 209.4 & 624.3 & 322.6 & 1902.3 & 435.4 & 59953.0 & 50794.3 & 25293.8 \\
\hline & B.-Frontier & 2976.3 & 16298.7 & 344.5 & 20918.7 & -159 & 40605 & 12213.2 & 307024.6 \\
\hline & HTKI & 11.6 & 84.4 & 30.8 & 145.0 & 38.0 & 7752.7 & 9943.5 & 4923.3 \\
\hline & DIV & 157 & 326 & 167 & 339 & 256 & 613 & 601 & 575 \\
\hline & FANI-Rate & 0.175 & 0.310 & 0.266 & 0.164 & 0.140 & 0.103 & 0.083 & 0.031 \\
\hline & Co-Inv Rate & 0.125 & 0.241 & 0.213 & 0.089 & 0.089 & 0.030 & 0.084 & 0.022 \\
\hline & NAFI-Rate & 0.049 & 0.073 & 0.064 & 0.076 & 0.087 & 0.086 & 0.145 & 0.036 \\
\hline \multirow{9}{*}{ 웅 } & Population(m) & 195.2 & 142.4 & 1205.6 & 1337.7 & 50.9 & 398.4 & 309.3 & 127.5 \\
\hline & GDP (b\$) & 1096.8 & 909.2 & 1243.7 & 3839.3 & 289.8 & 13415.7 & 13595.6 & 4648.5 \\
\hline & Frontier (TN) & 629.3 & 1035.7 & 2098.4 & 14859.1 & 369.9 & 69481.4 & 49924.6 & 38584.1 \\
\hline & B.-Frontier & 3013.7 & 25347.1 & -451.3 & 247823.6 & -261 & 30278.7 & 3636.8 & 185237.9 \\
\hline & HTKI & 36.1 & 69.0 & 269.8 & 3762.9 & 31.0 & 6782.0 & 8009.0 & 7073.3 \\
\hline & DIV & 302 & 364 & 362 & 538 & 246 & 615 & 599 & 567 \\
\hline & FANI-Rate & 0.219 & 0.253 & 0.394 & 0.131 & 0.233 & 0.105 & 0.121 & 0.019 \\
\hline & Co-Inv Rate & 0.136 & 0.169 & 0.222 & 0.066 & 0.140 & 0.041 & 0.120 & 0.015 \\
\hline & NAFI-Rate & 0.048 & 0.073 & 0.067 & 0.064 & 0.070 & 0.114 & 0.185 & 0.037 \\
\hline
\end{tabular}

Source: Authors' own elaboration. 


\section{References}

Akamatsu, K., 1962, "A historical pattern of economic growth in developing countries", The Developing Economies, 1(1), 3-25.

Aghion, P. \& Howitt, P., 1992, "A model of growth through creative destruction", Econometrica, vol. 60 , no. 2 , pp. 323-351.

Archibugi, D. \& Coco, A., 2004, "A New Indicator of Technological Capabilities for Developed and Developing Countries (ArCo)", World Development, vol. 32, no. 4, pp. 629-654.

Archibugi, D. \& Coco, A., 2005, "Measuring technological capabilities at the country level: A survey and a menu for choice", Research Policy, vol. 34, no. 2, pp. 175-194.

Archibugi, D., Denni, M. \& Filippetti, A., 2009, "The technological capabilities of nations: The state of the art of synthetic indicators", Technological Forecasting and Social Change, vol. 76, no. 7, pp. 917-931.

Ariffin, N. \& Figueiredo, P. N., 2004, "Internationalization of innovative capabilities: counter-evidence from the electronics industry in Malaysia and Brazil", Oxford Development Studies, vol. 32, no. 4, pp. 559-583.

Bell, M., 2009, "Innovation Capabilities and Directions of Development", STEPS Working Paper (Brighton: STEPS Centre), Working Paper no. 33.

Bell, M. \& Pavitt, K., 1993, “Technological Accumulation and Industrial Growth: Contrasts between Developed and Developing Countries", Industrial and Corporate Change, vol. 2, no.2, pp. 157-210.

Bell, M. \& Pavitt, K., 1995, "The development of technological capabilities" in Trade, Technology, and International Competitiveness, ed. I.U. Haqure, The World Bank, Washington, D.C., pp. 69-102. 
Bell, M. \& Pavitt, K., 1997, "Technological accumulation and industrial growth: contrasts between developed and developing countries", in Technology, Globalisation and Economic Performance, eds. D. Archibugi \& J. Michie, Cambridge University Press, Cambridge. Buckley, P.J., Clegg, J., Cross, A., Liu, X., Voss, H. \& Zheng, P., 2007, "The determinants of Chinese outward FDI", Journal of International Business Studies, vol. 38, no. 4, pp. 499-518. Castellani, D. \& Zanfei, A., 2006, Multinational Firms, Innovation and Productivity, Edward Elgar Publishing, Cheltenham, UK, Northampton, MA, USA.

Chen, D.H.C. \& Dahlman, C.J., 2004, Knowledge and Development: A Cross-Section Approach, Washington, D.C.

Cohen, W.M. \& Levinthal, D.A., 1989, "Innovation and Learning: The Two Faces of R \& D", The Economic Journal, vol. 99, no. 397, pp. 569-596.

Cohen, W.M. \& Levinthal, D.A., 1990, "Absorptive Capacity: A New Perspective on Learning and Innovation", Administrative Science Quarterly, vol. 35, no. 1, pp. 128-152.

Criscuolo, P. \& Narula, R., 2008, “A novel approach to national technological accumulation and absorptive capacity: Aggregating Cohen and Levinthal", The European Journal of Development Research, vol. 20, no. 1, pp. 56-73.

Damijan, J.P., Rojec, M., Majcen, B. \& Knell, M., 2013, "Impact of firm heterogeneity on direct and spillover effects of FDI: Micro-evidence from ten transition countries", Journal of Comparative Economics, vol. 41, no. 3, pp. 895-922.

de Rassenfosse, G., Dernis, H., Guellec, D., Picci, L. \& van Pottelsberghe de la Potterie, B., 2013, "The worldwide count of priority patents: A new indicator of inventive activity", Research Policy, vol. 42, no. 3, pp. 720-737.

Drivas, K., Economidou, C., Karkalakos, S. \& Tsionas, E.G., 2016, "Mobility of knowledge and local innovation activity", European Economic Review, vol. 85, pp. 39-61. 
Dutrenit, G., 2000, Learning and Knowledge Management in the Firm: From Knowledge Accumulation to Strategic Capabilities, Edward Elgar, Aldershot.

Eaton, J. \& Kortum, S., 2001, "Trade in capital goods", European Economic Review, vol. 45, no. 7, pp. 1195-1235.

Ernst, D., 2008, "Asia's 'Upgrading Through Innovation' Strategies and Global Innovation Networks: An Extension of Sanjaya Lall's Research Agenda", Transnational Corporations, vol. 17, no. 3, pp. 31-57.

Ernst, D., 2013, "Industrial Upgrading through Low-Cost and Fast Innovation-Taiwan's Experience", East-West Center Working Paper, Honolulu, vol. 133, September 2013, no. Economics Series.

European Commission, 2011, European Competitiveness Report 2011, European Commission, Luxembourg.

Fagerberg, J. \& Godinho, M., 2005, "Innovation and Catching-Up" in The Oxford Handbook of Innovation, in: Mowery, D.C., eds. J. Fagerberg \& R. Nelson, Oxford University Press, New York, pp. 514-543.

Findlay, R., 1978, "Relative Backwardness, Direct Foreign Investment, and the Transfer of Technology: A Simple Dynamic Model", The Quarterly Journal of Economics, vol. 92, no. 1, pp. 1-16.

Frietsch, R. \& Jung, T., 2009, Transnational Patents - Structures, Trends and Recent Developments, Expertenkommission Forschung und Innovation, Berlin.

Gereffi, G. \& Fernandez-Stark, K., 2011, Global Value Chain Analysis: A Primer, Duke University, Durham. 
Giroud, A., Jindra, B. \& Marek, P., 2012, "Heterogeneous FDI in Transition Economies - A Novel Approach to Assess the Developmental Impact of Backward Linkages", World Development, vol. 40, no. 11, pp. 2206-2220.

Grossman, G. \& Helpman, E., 1991, Innovation and Growth in the Global Economy, MIT Press, Massachusetts, USA.

Guellec, D. \& van Pottelsberghe de la Potterie, B., 2010, "Measuring the Internationalisation of the Generation of Knowledge: An Approach Based on Patent Data" in Handbook of Quantitative Science and Technology Research, eds. H.F. Moed, W. Glänzel \& U. Schmoch, Kluwer Academic Publishers, Dordrecht, pp. 645-662.

Guellec, D. \& van Pottelsberghe de la Potterie, B., 2001, "The internationalisation of technology analysed with patent data", Research Policy, vol. 30, no. 8, pp. 1253-1266.

Hobday, M., Rush, H. \& Bessant, J., 2004, "Approaching the innovation frontier in Korea: the transition phase to leadership", Research Policy, vol. 33, no. 10, pp. 1433-1457.

Hobday, M., 1995, "East Asian latecomer firms: Learning the technology of electronics", World Development, vol. 23, no. 7, pp. 1171-1193.

Holmes, T.J., McGrattan, E.R. \& Prescott, E.C., 2015, "Quid Pro Quo: Technology Capital Transfers for Market Access in China", The Review of Economic Studies, vol. 82, no. 3, pp. 1154-1193.

Humphrey, J. \& Schmitz, H., 2004, "Governance in Global Value Chains" in Local Enterprises in the Global Economy, ed. H. Schmitz, Edward Elgar Publishing, Cheltenham, pp. 95-109. Humphrey, J. \& Schmitz, H., 2002, "How does insertion in global value chains affect upgrading in industrial clusters?", Regional Studies, vol. 36, no. 9, pp. 1017-1027.

Imbs, J. \& Wacziarg, R., 2003, "Stages of Diversification", American Economic Review, vol. 93, no. 1 , pp. 63-86. 
Jindra, B., 2011, Internationalisation Theory and Technological Accumulation - An Investigation of Multinational Affiliates in East Germany, Palgrave Macmillan, Houndsmill, Basingstoke (UK).

Jindra, B., Hassan, S.S. \& Cantner, U., 2016, "What does location choice reveal about knowledge-seeking strategies of emerging market multinationals in the EU?", International Business Review, vol. 25, no. 1, Part A, pp. 204-220.

Kaplinsky, R. \& Morris, M., 2001, A Handbook for Value Chain Research, Institute of Development Studies, Brighton.

Keller, W., 2002, "Trade and the Transmission of Technology", Journal of Economic Growth, vol. 7, no. 1, pp. 5-24.

Keller, W. \& Yeaple, S.R., 2009, "Multinational Enterprises, International Trade, and Productivity Growth: Firm-Level Evidence from the United States", The Review of Economics and Statistics, vol. 91, no. 4, pp. 821-831.

Kim, L., 1997, Imitation to Innovation: The Dynamics of Korea's Technological Learning, Harvard Business School Press, Boston.

Koopmans, T.C., 1947, "Measurement Without Theory", The Review of Economics and Statistics, vol. 29, no. 3, pp. 161-172.

Krüger, J.J., 2008, "PRODUCTIVITY AND STRUCTURAL CHANGE: A REVIEW OF THE LITERATURE", Journal of Economic Surveys, vol. 22, no. 2, pp. 330-363.

Lall, S., 1992, Technological capabilities and industrialization.

Lee, K., 2005, "Making a Technological Catch-up: Barriers and opportunities", Asian Journal of Technology Innovation, vol. 13, no. 2, pp. 97-131.

Lee, K., 2013, Schumpeterian Analysis of Economic Catch-Up: Knowledge, Path-Creation, and the Middle-Income Trap, Cambridge University Press, Cambridge (UK). 
Lee, K. \& Kim, B., 2009, "Both Institutions and Policies Matter but Differently for Different Income Groups of Countries: Determinants of Long-Run Economic Growth Revisited", World Development, vol. 37, no. 3, pp. 533-549.

Li, P.P., 2010, "Toward a learning-based view of internationalization: The accelerated trajectories of cross-border learning for latecomers", Journal of International Management, vol. 16, no. 1, pp. 43-59.

Lin, J.Y., 2012, New Structural Economics: A Framework for Rethinking Development and Policy, The World Bank, Washington, DC.

Lin, J.Y. \& Rosenblatt, D., 2012, "Shifting patterns of economic growth and rethinking development", Journal of Economic Policy Reform, vol. 15, no. 3, pp. 171-194.

Makino, S., Lau, C. \& Yeh, R., 2002, "Asset-exploitation versus asset-seeking: Implications for location choice of foreign direct investment from newly industrialized economies", Journal of International Business Studies, vol. 33, no. 3, pp. 403-421.

Mansfield, E. 1961, "Technical Change and the Rate of Imitation", Econometrica, vol. 29, no. 4, pp. 741-766.

Mansfield, E. 1968, The Economics of Technological Change, New York, Norton \& Company Inc.

Marin, A. \& Bell, M., 2006, "Technology spillovers from Foreign Direct Investment (FDI): the active role of MNC subsidiaries in Argentina in the 1990s", The Journal of Development Studies, vol. 42, no. 4, pp. 678-697.

Mathews, J.A.. 2006, "Dragon multinationals: New players in 21st century globalization", Asia Pacific Journal of Management, vol. 23, no. 1, pp. 5-27.

Mathieu, A. \& van Pottelsberghe de la Potterie, B., 2010, "A note on the drivers of R\&D intensity", Research in World Economy, vol. 1, no. 1. 
Mazzoleni, R. \& Nelson, R.R., 2007, "Public research institutions and economic catch-up", Research Policy, vol. 36, no. 10, pp. 1512-1528.

Moncada-Paternò-Castello, P., Hervás, F., Grassano, N., Tübke, A. \& Vezzani, A., 2016, EU corporate R\&D intensity gap: structural features call for a better understanding of industrial dynamics, European Commission.

Narula, R., 2012, "Do we need different frameworks to explain infant MNEs from developing countries?", Global Strategy Journal, vol. 2, pp. 188-204.

Nelson, R.R., 1968, "A "Diffusion" Model of International Productivity Differences in Manufacturing Industry", The American Economic Review, vol. 58, no. 5, pp. 1219-1248. Nelson, R.R., 1995, "Recent Evolutionary Theorizing About Economic Change", Journal of Economic Literature, vol. 33, no. 1, pp. 48-90.

Nelson, R.R. \& Pack, H., 1999, "The Asian Miracle and Modern Growth Theory", The Economic Journal, vol. 109 , no. 457 , pp. 416-436.

OECD, 2004, Understanding Growth, Palgrave Macmillan, London.

OECD, 2010, Global Perspectives on Development, Shifting Wealth, Organisation for Economic Co-operation and Development, Paris.

Peneder, M., 2003, "Industrial structure and aggregate growth", Structural Change and Economic Dynamics, vol. 14, no. 4, pp. 427-448.

Pietrobelli, C. \& Rabellotti, R., 2011, "Global Value Chains Meet Innovation Systems: Are There Learning Opportunities for Developing Countries?", World Development, vol. 39, no. 7, pp. 1261-1269.

Radosevic, S., 1999, International technology transfer and catch-up in economic development, Edward Elgar Publishing, Cheltenham. 
Radosevic, S. \& Yoruk, D.E., 2004, "The growth of enterprise through entrepreneurship and network alignment" in International Industrial Networks and Industrial Restructuring in Central Europe, Russia and Ukraine, eds. S. Radosevic \& B. Sadowski, Dordrecht, Kluwer, pp. 109-109.

Radosevic, S. \& Yoruk, E., 2014, "Are there global shifts in the world science base? Analysing the catching up and falling behind of world regions", Scientometrics, vol. 101, pp. 1897-1924.

Radosevic, S. \& Yoruk, E., 2016, "Why do we need a theory and metrics of technology upgrading?", Asian Journal of Technology Innovation, vol. 24, pp. 8-32.

Ramamurti, R., 2012, "What is really different about emerging market multinationals?", Global Strategy Journal, vol. 1, pp. 41-47.

Rodrik, D. 2016, “Premature deindustrialization”, Journal of Economic Growth, vol. 21, no. 1, pp. 1-33.

Romer, P.M., 1990, "Endogenous Technological Change", Journal of Political Economy, vol. 98, no. 5, pp. S71-S102.

Rostow, W.W., 1960, The Stages of Economic Growth: A Non-Communist Manifest, 2nd enlarged edition 1971 edn, Cambridge University Press, Cambridge.

Sandven, T., Smith, K. \& Kaloudis, A. 2005, "Structural change, growth and innovation: the roles of medium and low tech industries, 1980-2000", in Low-tech Innovation in the Knowledge Economy, eds. H. Hirsch-Kreinsen, D. Jacobson, S. Laestadius \& K. Smith, P. Lang, Frankfurt, pp. 31-63.

Schmoch, U., 2008, Concept of a Technology Classification for Country Comparisons. Final Report to the WIPO. Revised in 2013. Available: http://www.wipo.int/export/sites/www/ ipstats/en/statistics/patents/pdf/wipo ipc technology.pdf. 
Solow, R.M., 1957, "Technical Change and the Aggregate Production Function", The Review of Economics and Statistics, vol. 39, no. 3, pp. 312-320.

Sturgeon, T.J. \& Gereffi, G., 2009, "Measuring Success in the Global Economy: International Trade, Industrial Upgrading, and Business Function Outsourcing in Global Value Chains", Transnational Corporations, vol. 18, no. 2, pp. 1-35.

Teece, D.J., 1976, The Multinational Corporation and the Resource Cost of Technology Transfer, Ballinger, Cambridge, MA.

Teece, D.J., 1977, "Technology Transfer by Multinational Firms: The Resource Cost of Transferring Technological Know-How", The Economic Journal, vol. 87, no. 346, pp. 242261.

Teece, D.J., 1986, "Profiting from technological innovation: Implications for integration, collaboration, licensing and public policy", Research Policy, vol. 15, no. 6, pp. 285-305. Verspagen, B., 1991, "A new empirical approach to catching up or falling behind", Structural Change and Economic Dynamics, vol. 2, no. 2, pp. 359-380.

Von Tunzelmann, G.N., 1995, Technology and Industrial Progress: The Foundations of Economic Growth, Edward Elgar Publishing, Aldershot.

Von Tunzelmann, N. \& Acha, V., 2005, "Innovation in 'low-tech' industries" in The Oxford Handbook of Innovation, eds. J. Fagerberg, D. Mowery \& R. Nelson, Oxford University Press, Oxford, pp. 407-432.

Wang, J. \& Blomström, M., 1992, "Foreign investment and technology transfer", European Economic Review, vol. 36, no. 1, pp. 137-155.

WEF, 2012, Global Competitiveness Report 2011-12, World Economic Forum, Geneva. 